\title{
Analysis of Teaching Styles of Teachers Regarding Various Variables
}

\begin{tabular}{|c|c|}
\hline \multicolumn{2}{|r|}{ Menekşe Eskici*a ${ }^{*}$ Seher Çetinkaya ${ }^{\text {b }}$} \\
\hline Article Info & Abstract \\
\hline DOI: $10.14686 /$ buefad.426636 & $\begin{array}{l}\text { The teaching styles that teachers have influence the modes of presentation of } \\
\text { information, their communication with students, and the way in which the classroom }\end{array}$ \\
\hline Article History: & and classroom activities are arranged. In this context, an examination of teaching \\
\hline 24.05 .2018 & styles of teachers regarding various variables will contribute to the field. From this \\
\hline 10.12.2018 & point of view, the aim was to determine whether the teaching styles of teachers differ \\
\hline Published $\quad 01.02 .2019$ & according to gender, branch, educational status, type of school, location of school, \\
\hline $\begin{array}{l}\text { Keywords: } \\
\text { Teaching Styles, } \\
\text { CORD Teaching Styles, } \\
\text { Demographic Characteristics }\end{array}$ & $\begin{array}{l}\text { professional seniority and average classroom size of the teachers. In the study, a } \\
\text { simple case causal-comparative pattern was used from quantitative research designs. } \\
\text { The data were obtained from } 248 \text { teachers working in Kirklareli in the academic } \\
\text { year 2016-2017. "Center for Occupational Research and Development (CORD) }\end{array}$ \\
\hline $\begin{array}{l}\text { Article Type: } \\
\text { Research Article }\end{array}$ & $\begin{array}{l}\text { Teaching Styles Inventory" was used as data collection tool in the research. As a } \\
\text { result of the research, it was concluded that the teaching styles of the teachers do } \\
\text { not meaningfully differ based on the gender, branch, educational status, the type of } \\
\text { school, the settlement where the school was located. However, professional } \\
\text { seniority and classroom size are variables that make a difference in teaching style } \\
\text { preferences of teachers. }\end{array}$ \\
\hline
\end{tabular}

\section{Öğretmenlerin Öğretim Stillerinin Çeşitli Değişkenler Açısından İncelenmesi}

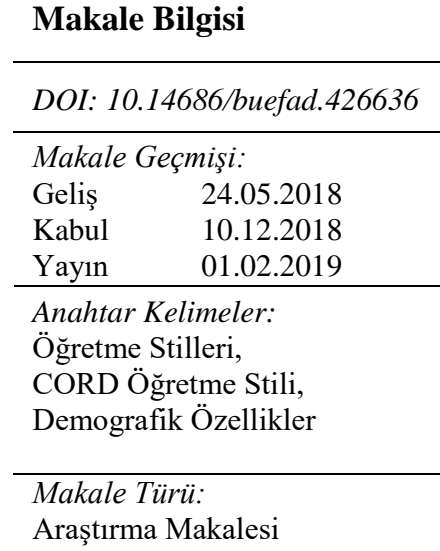

*Corresponding Author: menekeskici@ hotmail.com

${ }^{a}$ Dr. Öğr. Üyesi, Kırklareli Üniversitesi, , Kırklareli, Turkey. ORCID Number : 0000-0001-6217-3853

b Dr. Öğr. Üyesi, Ordu Universty, Ordu, Turkey. ORCID Number: 0000-0002-1330-106.

\begin{abstract}
$\ddot{\mathbf{O} z}$
Öğretmenlerin sahip oldukları öğretme stilleri bilgiyi sunuş tarzlarını, öğrencilerle iletişimlerini, sınıf içi ve sınıf dışı etkinlikleri düzenleme biçimlerini etkilemektedir. $\mathrm{Bu}$ bağlamda öğretmenlerin öğretme stillerinin çeşitli değişkenler açısından incelenmesinin alana katkı sağlayacağı düşünülmektedir. Bu düşünceden hareketle bu araştırmada öğretmenlerin öğretme stillerinin cinsiyet, branş, eğitim durumu, görev yapılan okul türü, okulun bulunduğu yerleşim birimi, mesleki kıdem ve öğretmenlerin görev yaptıkları okullardaki ortalama sınıf mevcudu değişkenlerine göre farklılaşıp farklılaşmadığının belirlenmesi amaçlanmıştır. Araştırmada nicel araştırma desenlerinden basit durum nedensel-karşılaştırmalı desen kullanılmıştır. Veriler 20162017 eğitim-öğretim yılında Kırklareli ilinde görev yapan 248 öğretmenden elde edilmiştir. Araştırmada veri toplama aracı olarak "Center for Occupational Research and Development (CORD) Öğretme Stilleri Envanteri” kullanılmıştır. Araştırma sonucunda öğretmenlerin öğretim stillerinin cinsiyet, branş, eğitim durumu, görev yapılan okul türü, okulun bulunduğu yerleşim birimine göre anlamlı bir fark göstermediği, mesleki kıdem ve sınıf mevcutlarının ise öğretmenlerin öğretim stilleri tercihlerinde fark yaratan değişkenler olduğu sonucuna ulaşılmıştır.
\end{abstract}




\section{Introduction}

Teachers encounter different students with different intelligence, abilities, interests, expectations and learning styles in their professional lives. Teachers must provide the appropriate teaching environment for students with these different characteristics. In the research conducted by Çetinkaya and Eskici (2018), it was concluded that teachers perceived teaching as a labor-demanding process. One of the key questions faced by teachers during this process is "how to teach". According to Kolb, knowledge is a combination of the transfer and perception of experience, and learning style is the method of perceiving and processing knowledge that is personally preferred (Kolb, 1984). The concept of learning style explains the individual differences in learning, based on the student's preference for using different phases of the learning cycle (Kolb \& Kolb, 2005). Just as students have their learning styles, teachers also have instructional styles. Teaching style is different from the teaching methods used by teachers. Two teachers can use small group discussion method and audio-visual tools in a classroom, but they both have different forms of application. This difference is the teaching style (Fischer \& Fischer, 1979). Teaching style includes behaviors (Cooper, 1999) of teachers, their preferences related to teaching method selection and instruments (Irby, 1995), teacher role within the classroom (Grasha, 1997), and classroom management of teachers (Cooper, 1999). According to Grasha (2003), teaching style is a special combination of teachers' behavior in the classroom environment, their performance, beliefs, needs and knowledge of pedagogy. The teaching style includes instructional behaviors such as how teachers provide information, how they interact with students and how they socialize with their students within the teaching-learning process.

Different scientists have classified learning styles and accordingly, teaching styles in different ways. Dunn and Dunn (1993) suggest that learning styles change according to environmental (sound, light, heat, seating arrangement), emotional factors (motivation, responsibility, job-task distribution, structure), social factors (single /dual, peer, team, adult/diversity), physiological factors (perceptual, snacks, time of day, movement) and psychological factors (analytic, holistic, reflective, thinker). Dunn and Dunn (1993) argue that the teacher influences the teaching style based on nine factors: teaching philosophy, student preferences, planning of teaching, grouping of students, classroom layout, teaching environment, features of teaching, teaching methods and evaluation techniques. Grasha (1997) classifies teaching styles as Expert, Formal Authority, Personal Model, Facilitator and Delegator. Fischer \& Fischer (1979) classified instructional styles as task-oriented, collaborativeplanner, student-centered, subject-centered, learning-centered and emotionally exuberant/calm.

One learning style classification was created by the Center for Occupational Research and Development (CORD). Teaching in this model is dealt with in two ways as "teaching goals" and "teaching methods" (CORD, 2005). Teaching goals are interpreted from two perspectives. The first point of view relates to the mechanics (memorization) and logical (comprehension) learning of the students in general. The second aspect concerns teachers' representation of abstract or feasible concepts and ideas in teaching activities (Bota \& Tulbure, 2015). CORD learning style instructional objectives have two dimensions of "learning-based" and "concept representation-based". The important symbols, principles and concepts in teaching for a teacher adapting the learning-based teaching style are taken as the knowledge in the book. Teachers use memorization more in this style. Rather than memorizing the definition of a concept, a teacher with the concept representation-based teaching style focuses on making students understand how and why the concept is defined as it is and associating learning with the real world. These two dimensions of learning-based and concept representation-based are classified in four group as A, B, C and D. The distribution of this classification is given in Figure 1.

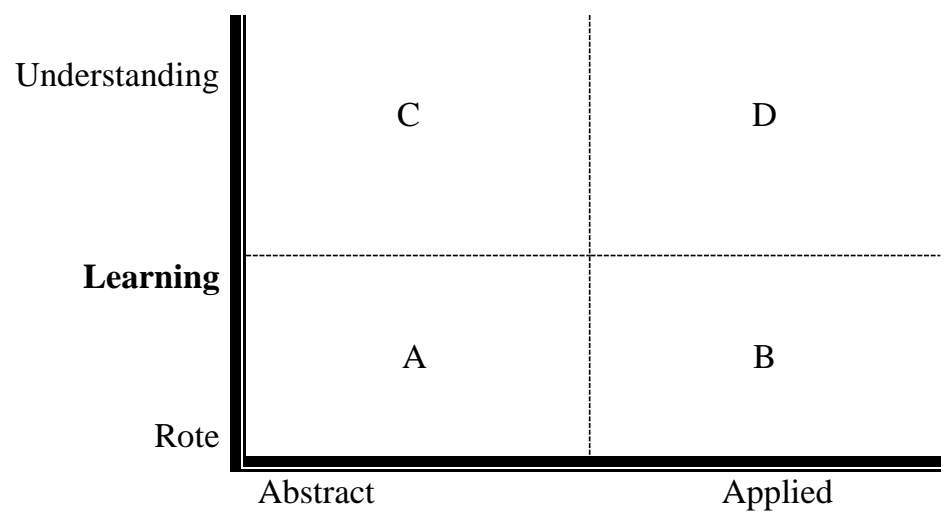

Concept Representation

Figure 1. Teaching Styles According to Teaching Goals (CORD, 2005). 
In style A the goal is mechanical learning and abstract teaching. The teacher prefers to begin teaching through memorizing and move toward analysis. For example, students memorize by repeating abstract facts such as multiplication tables.

B style is based on mechanical learning and practical knowledge (practical teaching). The teacher also focuses on practice as well as teaching memorizing. For example, students learn practical facts about the world.

Style $\mathrm{C}$ aims to learn through comprehension and theoretical teaching (abstract teaching). This style involves a change in teaching as it encourages students to understand the information conveyed through activities. The learning process is based on understanding, processing, and learning the information received. The teacher prefers to teach starting with analysis rather than by memorizing but does not focus on practical applications. For example, students learn abstract processes.

Style D aims to teach through comprehension and practical knowledge (practical teaching). This style focuses on practical, concrete knowledge that supports logical learning. Productivity and performance are essential. For example, students are presented with problems that they can formulate from the real world (CORD, 2005; Artvinli, 2010; Bota \& Tulbure, 2015)

For example; when providing the definition of the "education" concept, a teacher with the learning-based teaching style will give students the book definition and ask them to memorize the definition as it is or will first explain other concepts contained with the "education" concept and give a general definition wanting students to understand this definition. A teacher adapting the concept representation-based teaching style will begin from what the "education" concept means within the students' lives, explain with examples from daily life and begin from the students' definition of education wanting them to present examples from their own lives.

The second dimension of teaching styles is represented by teaching methods and observed from two perspectives. The first perspective takes the cognitive processing of concepts, thoughts, and theories into consideration and the second considers the organizational structure of the students (individual or groups). CORD learning-style teaching methods are classified into two dimensions as "cognitive processing-based" and "interaction-based". A teacher adapting the cognitive processed based teaching style will focus more on individual work and teacher-centered teaching activities. A teacher adapting the interaction-based teaching style will focus more on group work and student-teacher, student-student interactive teaching methods. These two dimensions of cognitive processing and interaction are also classified within themselves in four groups as A, B, C, D in itself. The distribution of this classification is given in Figure 2.

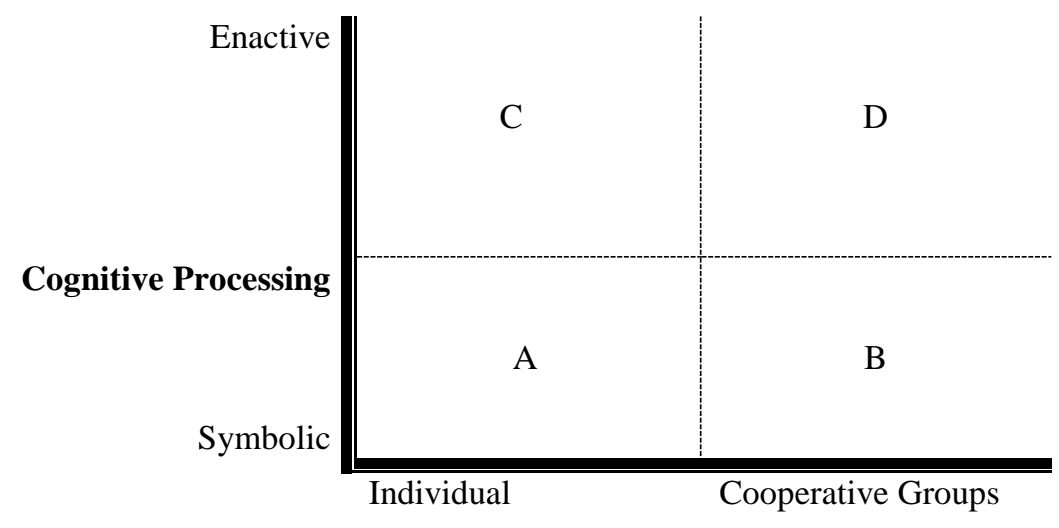

\section{Interaction}

Figure 2. Teaching Styles According to Teaching Methods (CORD, 2005)

Four teaching styles are also listed here (CORD, 2005; Artvinli, 2010; Bota \& Tulbure, 2015).

Style A requires symbolic cognitive processing and individual work. In other words, the teaching methods used by the teacher are mostly about the method of expression, and the aim is to work through the learning tasks individually. The teacher enables students to acquire knowledge through symbols and verbal means. For example, before explaining the topic, the teacher gives a preliminary reading task.

Style B involves symbolic cognitive processing and collaboration groups. The teacher allows students to acquire knowledge using symbols and verbal methods and prefers that the students work as a group. For example, students are divided into groups and requested to discuss problems. 
Style $\mathrm{C}$ involves processed or interpreted (actional) cognitive processing and individual work. According to this style, teachers encourage students to discover and understand new knowledge through individual study. For example, individual research activities may be performed.

Style D involves the cognitive processing and cooperative groups involving processing or interpretation (enactive). Through group work, students discover new knowledge and actively participate in the teaching process. The teacher enables students to learn through practical activities that are completed based on the cooperation of the students. For example, laboratory work based on team work (CORD, 2005; Artvinli, 2010; Bota \& Tulbure, 2015).

For example, if a teacher intending to conceptualize problems requiring four processes choses the cognitive processing-based teaching style, they will explain problem solutions based on their own examples and ask students to solve sample problems individually. A teacher adapting the interaction-based teaching style will have students solve four-process problems with group work, and perform teamwork related to solving problems with cooperative teaching techniques.

How can training applications be effective? Many attempts have been made through the years to answer this important question. The teaching styles that teachers use are part of the answer to this key question. According to Dunn and Dunn (1993), none of the research conducted is sufficient to explain how students achieve academic success, how they acquire and retain knowledge. People of different ages and different mental capacities learn in different ways, but the academic success of some students depends on the chosen teaching method. Studies show that motivation and academic achievement of students increase when they are taught using appropriate teaching methods for the learning styles of students (Miller 2001; Brown, 2003; Stitt-Gohdes, 2003, Mosston \& Ashworth, 2002). Teachers' teaching styles influence the modes of presentation of information, their communication with students, and the way in which the classroom and non-classroom activities are arranged. In this context, it is thought that the determination of teachers' teaching styles and their examination in terms of select variables will contribute to the field.

In the literature, there are studies investigating the teaching styles of teachers in terms of a range of variables. For example, Maden (2012) investigated the teaching styles of Turkish teachers according to Grasha's teaching styles and concluded that teaching styles differed in terms of gender, professional seniority and department graduated from. Gencel (2013) compared the teaching styles of teachers working in Turkey and the USA according to Grasha's teaching styles and revealed that the teaching styles of teachers in the USA and Turkey had statistically significant differences. In the USA the most commonly chosen teaching style were delegator/facilitation/expert and the least chosen teaching style was expert/formal authority. In Turkey the facilitator/personal model/expert was the most chosen teaching style, while the personal model/expert/formal authority was the least chosen teaching style. Üredi (2011) investigated the teaching styles of primary school teachers according to Grasha's teaching styles and concluded there was no significant correlation between gender, age, seniority, school type and school of final graduation with the chosen teaching style of teachers. They identified a significant correlation between the stages and branch of teachers with the chosen teaching styles. Sulaiman, Hassan and Yi (2011) concluded that teaching styles of primary and middle school teachers differed using a multiple intelligence approach. Cothran, Kulinna, Banville et al. (2005) investigated the teaching styles of teachers in 7 different countries according to Mosston's teaching styles and concluded teaching styles differed according to country. As explained above, it is possible to find studies investigating teaching styles of teachers in terms of a range of variables; however the number of studies dealing with CORD teaching styles are limited (Alias and Zakaria 2008; Artvinli, 2010; Bota \& Tulbure, 2015). In this study, the aim was to use CORD teaching styles and to investigate the teaching styles of teachers from different branches and stages in terms of a range of variables. From this aspect, our study is unique and it is considered the study results will contribute to the field. Based on this consideration, in this research the aim was was investigate the teaching styles of teachers in terms of a range of variables and the answers to the following questions were sought:

Do the teaching styles of teachers show a meaningful difference according to
a) gender,
b) branch
c) region where they are employed,
d) average number in the class,
e) educational status,
f) type of school they are employed in, and $\mathrm{g}$ ) their professional seniority? 


\section{Method}

The research can be described as a simple case causal-comparative research from the quantitative research models. In simple case causal-comparative research, the investigator tests the relationship between a categorical argument and a quantitative argument and whether this relationship is statistically significant (Johnson \& Christensen, 2014). During this research, the teaching styles of the teachers were examined by comparing the demographic characteristics of the teachers.

\section{Participants}

The maximum variation sampling method from purposeful sampling methods was used for the teacher sampling method. The aim was to examine teachers' situations in a wide range, including branch, the location of the schools they are employed in, the type of school they are employed in, gender and professional seniority. This information was obtained from 248 teachers who worked in Kirklareli during the 2016-2017 academic year. Demographic information of the study group is presented in Table 1.

Table 1. Demographic Information of the Study Group

\begin{tabular}{|c|c|c|c|c|c|c|c|c|}
\hline Gender & $\mathrm{N}$ & $\%$ & Settlement unit & $\mathrm{N}$ & $\%$ & Class size & $\mathrm{N}$ & $\%$ \\
\hline Female & 158 & 63.7 & Province & 102 & 41.1 & $0-20$ & 111 & 44.8 \\
\hline Male & 90 & 36.3 & District & 117 & 47.2 & $21-25$ & 41 & 61.3 \\
\hline Branch & & & Town & 20 & 8.1 & $26-30$ & 55 & 83.5 \\
\hline Verbal & 53 & 21.4 & Village & 9 & 3.6 & $31-35$ & 41 & 14.9 \\
\hline Numerical & 68 & 27.4 & Length of service & & & School type & & \\
\hline Language & 22 & 8.9 & $0-5$ & 82 & 33.1 & Primary school & 75 & 30.2 \\
\hline Art & 10 & 4.0 & $6-10$ & 30 & 12.1 & Middle School & 82 & 33.1 \\
\hline Physical training & 11 & 4.4 & $11-15$ & 35 & 14.1 & High school & 91 & 36.7 \\
\hline Class & 78 & 31.5 & $16-20$ & 28 & 11.3 & & & \\
\hline Pre-school & 6 & 2.4 & 21-over & 73 & 29.4 & & & \\
\hline \multicolumn{9}{|l|}{ Education status } \\
\hline Completing degree & 15 & 6.0 & & & & & & \\
\hline Bachelor's degree & 215 & 86.7 & & & & & & \\
\hline Master's degree & 18 & 7.3 & & & & & & \\
\hline
\end{tabular}

\section{Data Collection Tools}

The "CORD Teaching Styles Inventory" was used as data collection tool in the research. Developed by the Center for Occupational Research and Development (CORD), this inventory consists of 12 items and four situations under each item. In these sub-situations, the teachers' thinking style or feelings related to teaching methods and classroom behavior are given. The Teaching Styles Inventory developed by CORD was adapted to Turkish by Artvinli (2010). There are four different teaching styles within the measurement. These styles are; 1. Learning-based (scale between memorization and cognition), 2. Concept Representation Based (scale between abstract/theoretical and application/adaptation), 3. Cognitive Processing Based (scale between symbolic/figurative and real/enaction) and 4. Interaction Based (scale between individual and cooperative groups). The Cronbach Alpha internal consistency coefficient was found as .88 by Artvinli (2010). The reliability coefficients of the four subscales of the inventory were .91 for Learning Based, 0.80 for Concept Representation Based, .89 for Cognitive Processing Based, and .92 for Interaction Based Subscale. A preliminary application performed with 183 individuals by the researchers in this study found the Cronbach Alpha internal consistency coefficient was .70. The reliability coefficients of the four subscales of the inventory were found to be .72 for Learning Based, .81 for Concept Representation Based, .79 for Cognitive Processing Based, and .82 for Interaction Based Subscale.

\section{Analysis of the data}

The analysis of the data was carried out using SPSS 17. In general, frequency, arithmetic mean and percentages were calculated. The Kolmogorov-Smirnov test was also applied to determine whether the data are normally distributed, and the result is that the data do not show normal distribution. For this reason, the Mann Whitney-U test and Kruskal Wallis-H test, which are non-parametric tests, were used for the difference analysis.

\section{Findings}

Findings related to the research are presented in tables. 
Table 2. Mann Whitney-U Test Results of Teachers' Teaching Styles According to Gender Variable

\begin{tabular}{|c|c|c|c|c|c|}
\hline Gender & $\mathbf{N}$ & Learning-based & $\begin{array}{l}\text { Concept } \\
\text { representation based }\end{array}$ & $\begin{array}{l}\text { Cognitive } \\
\text { process based }\end{array}$ & $\begin{array}{l}\text { Interaction } \\
\text { based }\end{array}$ \\
\hline & & $\bar{X}$ & $\bar{X}$ & $\bar{X}$ & $\bar{X}$ \\
\hline Female & 158 & 121.68 & 123.60 & 127.22 & 127.24 \\
\hline Male & 90 & 129.44 & 126.08 & 119,73 & 119.68 \\
\hline Total & 248 & & & & \\
\hline $\begin{array}{l}\text { Test } \\
\text { result }\end{array}$ & & $\begin{array}{l}Z=-.82 \\
p>.05\end{array}$ & $\begin{array}{l}Z=-.26 \\
p>.05\end{array}$ & $\begin{array}{c}Z=-.79 \\
p>.05\end{array}$ & $\begin{array}{l}\mathrm{Z}=-.80 \\
\mathrm{p}>.05\end{array}$ \\
\hline
\end{tabular}

Table 2 shows the results of the Mann Whitney-U test to determine whether there is a meaningful difference in the teaching styles of the teachers in the study group compared to the gender variable. According to the findings, the difference between the arithmetic mean of all the styles (learning $Z=-.82$, $p>.05$, concept representation $Z=-$ .26 , $\mathrm{p}>.0$, cognitive processing $\mathrm{Z}=-.79, \mathrm{p}>.05$, interaction $\mathrm{Z}=-.80, \mathrm{p}>.05$ ) in the groups is not statistically significant. According to these findings, it can be said that teachers' teaching styles do not differ according to their gender. Though the teaching styles of teachers do not differ according to gender, when rank mean points are investigated, it appeared female teachers mainly chose interaction-based (127.24) and cognitive processing-based (127.22) teaching styles, while male teachers mainly chose learning-based (129.44) teaching styles.

Table 3. Kruskal Wallis-H Test Results of Teachers' Teaching Styles According to Branch

\begin{tabular}{|c|c|c|c|c|c|}
\hline Branch & $\mathbf{N}$ & Learning-based & $\begin{array}{l}\text { Concept } \\
\text { representation } \\
\text { based }\end{array}$ & $\begin{array}{l}\text { Cognitive process } \\
\text { based }\end{array}$ & Interaction based \\
\hline & & $\bar{X}$ & $\bar{X}$ & $\bar{X}$ & $\bar{X}$ \\
\hline Verbal & 53 & 141.49 & 133.31 & 104.11 & 115.84 \\
\hline Numerical & 68 & 110.65 & 131.48 & 130.63 & 126.56 \\
\hline Language & 22 & 124.66 & 114.84 & 141.70 & 116.66 \\
\hline Art & 10 & 119.25 & 109.95 & 128.70 & 132.60 \\
\hline Class & 78 & 124.75 & 122.78 & 129.73 & 122.47 \\
\hline $\begin{array}{l}\text { Physical } \\
\text { education }\end{array}$ & 11 & 137.00 & 108.14 & 93.77 & 153.23 \\
\hline Pre-school & 6 & 113.42 & 79.67 & 153.33 & 166.67 \\
\hline Total & 248 & & & & \\
\hline Test result & & $\mathrm{KW} \mathrm{X}=6.07 \mathrm{p}>.01$ & $\mathrm{KW} \mathrm{X} \mathrm{X}^{2}=55.23 \mathrm{p}>.01$ & $\mathrm{KW} \mathrm{X}=9.53 \mathrm{p}>.01$ & $\mathrm{KW} \mathrm{X}^{2}=5.15 \mathrm{p}>.01$ \\
\hline
\end{tabular}

Table 3 shows the Kruskal Wallis-H test results to determine whether the teachers who constituted the study group display a meaningful difference in teaching styles based on branch. The difference between the arithmetic mean of the teaching styles (learning $X^{2}=6.07, p>.01$, concept representation $X^{2}=55.23, p>.0$, cognitive processing $\mathrm{X}^{2}=9.53, \mathrm{p}>.01$, interaction $\mathrm{X}^{2}=5.15, \mathrm{p}>.01$ ) in the findings was not statistically significant. It can be said that the teaching styles of the teachers did not differ according to their branch. When the rank mean points related to teaching style according to branch are investigated, verbal teachers chose learning-based (141.49), numerical teachers chose concept representation-based (131.48), language teachers chose cognitive processing-based (141.70), class teachers chose cognitive processing-based (129.73), art teachers chose interaction-based (132.60), physical education teachers chose interaction-based (153.23) and preschool teachers chose interaction-based (166.67) teaching styles.

Table 4. Kruskal Wallis-H Test Results of Teachers' Teaching Styles According to the settlement Unit

\begin{tabular}{|c|c|c|c|c|c|}
\hline $\begin{array}{l}\text { Settlement } \\
\text { unit }\end{array}$ & $\mathbf{N}$ & Learning-based & $\begin{array}{l}\text { Concept } \\
\text { representation } \\
\text { based }\end{array}$ & $\begin{array}{l}\text { Cognitive } \\
\text { process based }\end{array}$ & Interaction based \\
\hline & & $\bar{X}$ & $\bar{X}$ & $\bar{X}$ & $\bar{X}$ \\
\hline Province & 102 & 136.04 & 125.27 & 117.75 & 119.28 \\
\hline District & 117 & 114.31 & 124.72 & 131.38 & 124.59 \\
\hline Town & 20 & 129.15 & 124.05 & 117.60 & 140.93 \\
\hline Village & 9 & 115.83 & 113.89 & 126.78 & 145.94 \\
\hline Total & 248 & & & & \\
\hline Test result & & $\begin{array}{l}\mathrm{KW} \mathrm{X} X^{2}=5,24 \\
\mathrm{p}>.01\end{array}$ & $\begin{array}{l}\mathrm{KW} \mathrm{X}^{2}=-21 \\
\mathrm{p}>.01\end{array}$ & $\begin{array}{l}\mathrm{KW} \mathrm{X} \mathrm{X}^{2}=2.18 \\
\mathrm{p}>.01\end{array}$ & $\mathrm{KW} \mathrm{X} \mathrm{X}^{2}=2.41 \mathrm{p}>.01$ \\
\hline
\end{tabular}


According to the results of the Kruskal Wallis-H test, the teachers' teaching styles (learning $\mathrm{X}^{2}=5.24, \mathrm{p}>.01$, concept representation $X^{2}=-21, p>.01$, cognitive processing $X^{2}=2.18, p>.01$, interaction $X^{2}=2.41, p>.01$ ) do not show any statistically significant difference based on the settlement where they work. When rank mean points are investigated, teachers working in villages and towns chose interaction-based (village $=145.93$, town $=140.93$ ) teaching style, while teachers working in provincial centers chose learning-based (136.04) teaching style.

Table 5. Kruskal Wallis-H Test Results of the Teachers' Teaching Styles According to the Class Size

\begin{tabular}{|c|c|c|c|c|c|}
\hline Class size & $\mathbf{N}$ & Learning-based & $\begin{array}{l}\text { Concept } \\
\text { representation } \\
\text { based }\end{array}$ & $\begin{array}{l}\text { Cognitive } \\
\text { process based }\end{array}$ & Interaction based \\
\hline & & $\bar{X}$ & $\bar{X}$ & $\bar{X}$ & $\bar{X}$ \\
\hline-20 & 111 & 118.41 & 107.11 & 131.86 & 147.22 \\
\hline $21-25$ & 41 & 133.16 & 136.94 & 120.94 & 102.89 \\
\hline $26-30$ & 55 & 120.09 & 130.77 & 125.92 & 117.43 \\
\hline $30+$ & 41 & 138.23 & 150.72 & 106.52 & 94.09 \\
\hline Total & 248 & & & & \\
\hline Test result & & $\begin{array}{l}\mathrm{KW} \mathrm{X} X^{2}=3.12 \\
p>.01\end{array}$ & $\begin{array}{l}\mathrm{KW} X^{2}=-13.70 \\
p<.01\end{array}$ & $\begin{array}{l}\mathrm{KW} X^{2}=3.90 \\
\mathrm{p}>.01\end{array}$ & $\begin{array}{l}\mathrm{KW} \mathrm{X} \mathrm{X}^{2}=22.92 \\
\mathrm{p}<.01\end{array}$ \\
\hline
\end{tabular}

Table 5 shows the results of the Kruskal Wallis-H test to determine whether the teaching styles of the teachers who constituted the study group showed a meaningful difference based on the number in the class. According to the findings obtained, the difference between the arithmetic mean of concept representation-based teaching styles $\left[\mathrm{KW} \mathrm{X} \mathrm{X}^{2}=-13.70, \mathrm{p}<0.01\right]$ and interaction-based $\left[\mathrm{KW} \mathrm{X} \mathrm{X}^{2}=22.92, \mathrm{p}<0.01\right]$ teaching styles was statistically significant. The Mann Whitney-U test was conducted to determine which groups the difference was found between, the result indicates that teachers with 20 or fewer in their class were significantly less likely to use teaching styles based on conceptual explanations than teachers with 30 or more in their classroom $(\mathrm{U}=1462, \mathrm{p}$ $<.05)$. Also, it was concluded that teachers with 20 or fewer in their class used significantly higher levels of interaction-based teaching style than teachers with 30 or more in their class $(U=1325, p<.05)$. When rank mean points are investigated, teachers with $21-25,26-30$ and 31 or more in their class mainly chose concept representation-based $(21-25=136.94,26-30=130.77,31$ or more $=150.72)$ teaching style, while teachers with 20 or fewer in their class mainly chose interaction-based (147.22) teaching style.

Table 6. Kruskal Wallis-H Test Results of Teachers' Teaching Styles According to Educational Status

\begin{tabular}{|c|c|c|c|c|c|}
\hline $\begin{array}{l}\text { Education } \\
\text { Status }\end{array}$ & $\mathbf{N}$ & Learning-based & $\begin{array}{l}\text { Concept } \\
\text { representation } \\
\text { based }\end{array}$ & $\begin{array}{l}\text { Cognitive } \\
\text { process based }\end{array}$ & Interaction based \\
\hline & & $\bar{X}$ & $\bar{X}$ & $\bar{X}$ & $\bar{X}$ \\
\hline $\begin{array}{l}\text { Completing } \\
\text { degree }\end{array}$ & 15 & 108.70 & 140.53 & 137.57 & 104.20 \\
\hline $\begin{array}{l}\text { Bachelor's } \\
\text { degree }\end{array}$ & 215 & 124.75 & 123.51 & 125.20 & 125.67 \\
\hline Master's degree & 18 & 134.69 & 122.97 & 105.25 & 127.47 \\
\hline Total & 248 & & & & \\
\hline Test result & & $\begin{array}{c}\mathrm{KW} \mathrm{X} \mathrm{X}^{2}=1.10 \\
\mathrm{p}>.01\end{array}$ & $\begin{array}{l}\mathrm{KW} \mathrm{X}^{2}=.80 \\
\mathrm{p}>.01\end{array}$ & $\begin{array}{l}\mathrm{KW} \mathrm{X} \mathrm{X}^{2}=1.82 \\
\mathrm{p}>.01\end{array}$ & $\mathrm{KW} \mathrm{X}^{2}=1.30 \mathrm{p}>.01$ \\
\hline
\end{tabular}

The results of the Kruskal Wallis-H test to determine whether the teaching styles of the teachers of the study group showed a meaningful difference according to the educational status variable of the teachers are given in Table 6. Teachers did not show any statistically significant difference in teaching styles (learning $X^{2}=1.10, p>.01$, concept representation $X^{2}=-.80, p>.01$, cognitive processing $X^{2}=1.82, p>.01$, interaction $X^{2}=1.30, p>.01$ ) based on educational status. When rank mean points are investigated, teachers completing their degree chose concept representation-based (140.53) teaching style, teachers with a degree chose interaction-based (125.67) teaching style and teachers with a master's degree chose learning-based (134.69) teaching style. 
Table 7. Kruskal Wallis-H Test Results of Teachers' Teaching Styles According to School Type

\begin{tabular}{|c|c|c|c|c|c|}
\hline School Type & $\mathbf{N}$ & Learning-based & $\begin{array}{l}\text { Concept } \\
\text { representation } \\
\text { based }\end{array}$ & $\begin{array}{l}\text { Cognitive } \\
\text { process based }\end{array}$ & Interaction based \\
\hline & & $\bar{X}$ & $\bar{X}$ & $\bar{X}$ & $\bar{X}$ \\
\hline $\begin{array}{l}\text { Primary } \\
\text { school }\end{array}$ & 75 & 128.47 & 115.15 & 137.63 & 119.17 \\
\hline $\begin{array}{l}\text { Middle } \\
\text { School }\end{array}$ & 82 & 120.78 & 121.73 & 130.20 & 125.99 \\
\hline $\begin{array}{l}\text { High school } \\
\text { Total }\end{array}$ & $\begin{array}{l}91 \\
248\end{array}$ & 124.58 & 134.71 & 108.54 & 127.55 \\
\hline Test result & & $\begin{array}{l}\mathrm{KW} \mathrm{X} \mathrm{X}^{2}=.45 \\
\mathrm{p}>.01\end{array}$ & $\begin{array}{l}\mathrm{KW} \mathrm{X} \mathrm{X}^{2}=.3 .25 \\
\mathrm{p}>.01\end{array}$ & $\begin{array}{l}\mathrm{KW} \mathrm{X}=1.82 \\
\mathrm{p}>.01\end{array}$ & $\begin{array}{l}\mathrm{KW} \mathrm{X} \mathrm{X}^{2}=1.30 \\
\mathrm{p}>.01\end{array}$ \\
\hline
\end{tabular}

As can be seen from Table 7, based on the results of the Kruskal Wallis-H test, the teachers' teaching styles (learning $\mathrm{X}^{2}=.45, \mathrm{p}>.01$, concept representation $\mathrm{X}^{2}=3.25 \mathrm{p}>.01$, cognitive processing $\mathrm{X}^{2}=1.82, \mathrm{p}>.01$, interaction $\mathrm{X}^{2}=1.30, \mathrm{p}>.01$ ) do not show statistically significant differences according to the type of school they work in. When rank mean points are investigated, teachers working in primary schools chose cognitive processing-based (137.53) teaching style, teachers working in middle schools chose cognitive processing-based (130.20) teaching style and teachers working in high schools chose concept representation-based (134.71) teaching styles.

Table 8. Kruskal Wallis-H Test Results of Teachers' Teaching Styles According to Professional Seniority

\begin{tabular}{|c|c|c|c|c|c|}
\hline $\begin{array}{ll}\text { Length } & \text { of } \\
\text { service } & \end{array}$ & $\mathbf{N}$ & Learning-based & $\begin{array}{l}\text { Concept } \\
\text { representation } \\
\text { based }\end{array}$ & $\begin{array}{l}\text { Cognitive } \\
\text { process based }\end{array}$ & Interaction based \\
\hline & & $\bar{X}$ & $\bar{X}$ & $\bar{X}$ & $\bar{X}$ \\
\hline $0-5$ & 82 & 117.23 & 113.59 & 121.97 & 145.28 \\
\hline $6-10$ & 30 & 115.30 & 115.13 & 148.30 & 126.72 \\
\hline $11-15$ & 35 & 111.69 & 132.04 & 129.40 & 129.56 \\
\hline $16-20$ & 28 & 138.09 & 146.95 & 100.45 & 105.29 \\
\hline $21+$ & 73 & 137.38 & 128.38 & 124.44 & 105.19 \\
\hline Total & 248 & & & & \\
\hline Test result & & $\begin{array}{l}\mathrm{KW} \mathrm{X}^{2}=5.84 \\
p>.01\end{array}$ & $\begin{array}{l}\mathrm{KW} \mathrm{X}^{2}=-5.77 \\
\mathrm{p}>.01\end{array}$ & $\begin{array}{l}\mathrm{KW} X^{2}=6.75 \\
p>.01\end{array}$ & $\begin{array}{l}\mathrm{KW} \mathrm{X} \mathrm{X}^{2}=11.48 \\
\mathrm{p}<.01\end{array}$ \\
\hline
\end{tabular}

Table 8 shows the results of the Kruskal Wallis-H test to determine whether the teaching styles of the teachers who constituted the study group showed a significant difference according to the seniority of the teachers. According to the findings obtained, the difference between the arithmetic mean of the teaching styles based on interaction $[\mathrm{KW}$ X2 $=11.48, \mathrm{p}<0.01]$ was found to be statistically significant. The Mann Whitney-U test was conducted to determine which groups caused this difference, it was concluded that the teachers who have length of service between 0-5 years use the interaction-based teaching style more significantly than teachers who have a length of service of between 16-20 $(\mathrm{U}=2035, \mathrm{p}<.01)$ and $(\mathrm{U}=774, \mathrm{p}<.01)$ over 21 years. When rank mean points are investigated, teachers with 0-5 years of service chose interaction-based (145.28) teaching style, teachers with 6-10 years of service chose cognitive processing-based (148.30) teaching style, teachers with 11-15 years of service whose concept representation-based (146.95) teaching style and teachers with 21 years or more of service chose learning-based teaching style.

\section{Discussion and Conclusion}

Many factors can play a role in a teacher's preferred teaching style. According to Grasha (2002), the teaching style influences the characteristics and abilities of students, teacher's desire to develop efficient relationships with people, the need for teachers to control the learning task, the learning style of the students and the situational needs of the students (urgent needs and wishes of that moment or day). In addition to these factors, this study investigates teachers' teaching styles in terms of different variables, since demographic characteristics such as their experiences, preservice education, and type of school they are working in may also be decisive in teaching style preferences.

When the findings obtained from the research are examined, the difference between the teaching styles of the teachers according to the gender variable was not statistically significant. However, Artvinli (2010) found in his research about geography teacher that conceptual representation-based and interaction-based teaching styles differed in favor of female teachers, while the learning-based style differed in favor of male teachers. On the other hand, there was no significant difference between male and female geography teachers for teaching style based on 
cognitive processing. In this study, female teachers mainly chose interaction-based teaching style while male teachers mainly chose learning-based teaching style according to rank mean points. Though teaching styles of female and male teachers did not show statistically significant differences, this is similar to the study by Artvinli (2010). There are studies in the literature showing the gender variable does not create a difference in teaching style of teachers/teacher candidates (Can; 2011; Üredi, 2011; Zeng, 2016), while there are also studies identifying differences (Lacey, Saleh and Gorman 1998; Maden, 2012). In this situation it is difficult to say that gender is a determinant of the teaching style of teachers.

According to the findings obtained from the research the teachers' teaching styles did not differ statistically according to branch. Verbal lesson teachers (history, geography, social studies) had higher preferences for learning-based teaching style (more memorization) than numerical lesson teachers (mathematics, physics, chemistry). At the same time, though art, physical education and preschool teachers chose interaction-based teaching style more compared to other branch teachers, the difference was not statistically significant. Alias and Zakaria, (2008), in their research about university lecturers, found that technical education faculty members are less likely to prefer instructional teaching based on conceptual representation compared to engineering, technology management, and information technology faculty members, and found it to be alarming. This is because they argue that teachers need to learn by understanding abstract concepts and they state that the teaching style based on the concept representation should be preferred for the teaching of future teachers instead of the learning-based teaching style. Perhaps, as Byrne (2007) points out, teachers define the style of teaching according to the culture that is found within the school independently of the subjects taught.

According to another finding in the research, teachers' teaching styles did not significantly differ according to the settlement unit where they work. According to rank mean points, teachers working in villages and towns mainly chose interaction-based teaching style and teachers working in provincial centers mainly chose learning-based teaching style. Teaching styles of teachers working in different countries may differ according to country (Cothran et al., 2005; Gencel, 2013); however, it can be said the teaching style of teachers does not differ according to settlement unit.

When the findings obtained from the research were examined, it was concluded that the class size variable caused a difference in teaching preferences of teachers. It was concluded that teachers with 20 or fewer in their class used teaching style based on concept representation significantly less than teachers with 30 or more in their class. Also, it was concluded that teachers with 20 or fewer in their class use teaching style based on interaction significantly more than teachers with 30 or more in their class. According to the results of the research, teachers with smaller class sizes use teaching style based on interaction more often and conceptual explanations less often. The results obtained from the study are in parallel with those obtained from the study by Artvinli (2010). Crowded class numbers do not give teachers the opportunity to do group work.

When findings related to the teaching style according to educational status of teachers are investigated, no significant difference in teaching styles was identified. Artvinli (2010) concluded that geography teachers who graduated from education institutes applied more teacher-centered and behavioral teaching styles, including teaching the students through symbols and verbal methods, individual work without interaction, and listening to lessons. He also stated that teachers who had undergone postgraduate education preferred interaction-based instructional techniques and stated that the results of the study were supported by research by Zhang (2007). Genc and Ogan-Bekiroglu (2004) suggest that teachers prefer more student-centered teaching styles as their level of education increases. However, the results of this research there was no significant differences in teaching styles of teachers according to their educational status. Additionally, according to rank mean points, the mean for interaction-based teaching style was higher among teachers with graduate and masters degrees compared to teachers who were still completing their degree. However, it is noteworthy that the highest rank mean points for the learning-based teaching style were among teachers with masters degrees.

When findings related to teaching style according to the level of the school (primary school, middle school, high school) are investigated, no significant difference in teachers' teaching styles were identified. According to rank mean points, teachers working in primary and middle schools were identified to choose more cognitive processing-based teaching style, while teachers working in high schools chose concept representation-based teaching style. Artvinli (2010) concluded that teaching styles of geography teachers difference for the concept representation-based teaching style according to the type of school the teachers worked in. Accordingly, for the concept representation-based teaching style, there was a difference in favor of teachers working in Anatolian, Science and Social Sciences high schools among teachers working in Anatolian, Science, Social Sciences high schools and vocational high schools. According to Artvinli (2010), this difference is interpreted as due to more memorization-based geography education in the first group of schools due to university exam concerns. In this 
research, the mean for concept representation-based teaching style was higher for high school teachers compared to primary and middle school teachers which may be due to concerns about university exam preparation.

Another finding of the research is that the seniority variable created a difference in teachers' choice of teaching style. It was concluded that teachers with 0-5 years of experience chose interaction-based teaching style at significantly higher rates compared to teachers with 16-20 years and 21 years or more experience. Similar results were obtained in studies by Artvinli (2010) and Alias and Zakaria (2008). In the teaching program applied in Turkey, it is expected that cooperative-based teaching methods be used and that students not just receive information passively but they should structure information through activities. In other words the students should be active and the teacher should act as a guide. It is necessary to organize teaching based on a constructivist approach (MEB, 2005). Programs in educational faculties allow the opportunity to gain knowledge, abilities and values, in addition to candidates gaining teaching experience in a systematic and planned fashion. This experience is organized within faculty-school cooperation. In Turkey, this experience organized within faculty-school cooperation may be assessed as an example of the constructivist approach to teaching style (Kaya, 2016). In this context, it may be considered that teachers with 1-5 years of experience were raised with a constructivist approach during preservice education. It may be that teachers with greater seniority remain linked to more traditional methods. Teachers adapting student-centered teaching styles are more successful in preparing constructivist environments (Üredi and Üredi 2009). As teacher candidates cannot teach without learning, the topics of teachinglearning concepts, strategies and styles that prevail while they are attending teaching training programs have great importance. Thus, it will be possible to train tutors with wider foresight in terms of method components (Babadoğan, 2000).

According to the results of the research, teachers with low class numbers chose interaction-based teaching style. In this context, it may be suggested that studies be completed to lower class numbers in order to provide teachers the opportunity for in-class activities and group work.

According to another result obtained in the research, considering teachers with less seniority chose interactionbased teaching style more often, in-service training seminars may be arranged to detach teachers with more experienced from traditional teaching methods.

More extensive research could be completed to investigate the effects of variables such as gender, branch, education status, school type, etc. on teaching styles of teachers. Some qualitative research could be performed to obtain the opinions of the teachers about which variables determine their teaching style preferences.

\section{Acknowledgement}

This study was presented at IX. International Congress of Educational Research as abstract. 


\section{Öğretmenlerin Öğretme Stillerinin Çeşitli Değiş̧kenler Açısından İncelenmesi}

\section{Giriş}

Öğretmenler meslek yaşamlarında birbirinden farklı zeka, yetenek, ilgi, beklenti ve öğrenme stiline sahip öğrencilerle karşılaşırlar. Öğretmenler, bu farklı özellikteki öğrencilere uygun öğretim ortamını sağlamak durumundadır. Çetinkaya ve Eskici (2018) tarafindan yapılan araştırmada öğretmenlerin öğretmeyi emek gerektiren bir süreç olarak algıladıkları sonucu elde edilmiştir. Bu süreç içerisinde öğretmenlerin karşılaştıkları kilit sorulardan biri de "nasıl" öğretelim sorusudur. Kolb'a göre bilgi, deneyimin transferi ve algılanmasının birleşiminden elde edilen sonuçlardır ve öğrenme stili bilgiyi algılama ve işlemede kişisel olarak tercih edilen yöntemdir (Kolb,1984). Öğrenme stili kavramı, öğrencinin öğrenme döngüsünün farklı evrelerini kullanmaya yönelik tercihine dayanarak, öğrenmedeki bireysel farklılıkları açıklar ( Kolb \& Kolb, 2005). Öğrencilerin kendine özgü öğrenme stilleri olduğu gibi öğretmenlerin de öğretim stilleri vardır. Öğretim stili öğretim yöntemlerinden farklı olarak öğretmenin kullandığı öğretim tarzıdır. İki öğretmen de bir sınıfta küçük grup tartışması yöntemi ve görsel-işitsel araçlar kullanabilir ancak her ikisinin de uygulama şekli farklıdır. Bu fark öğretim stiline işaret etmektedir (Fischer \&Fischer,1979). Öğretim stilli, öğretim faaliyetlerinde öğretmenlerin yöntem seçimi ve araçgereç tercihlerini (Irby, 1995), öğretmenin sınıftaki rolünü (Grasha, 1997), öğretmenlerin sınıfı yönetmeye yönelik olarak gösterdiği davranışları (Cooper,1999) içermektedir. Grasha (2003)'ya göre öğretim stili, öğretmenin sınıf ortamındaki davranışlarının, performansının, inançlarının, ihtiyaçlarının ve pedagoji hakkındaki bilgilerinin özel bir birleşimidir. Öğretim stili, öğretme-öğrenme süreci içinde öğretmenlerin bilgiyi nasıl sunduğu, öğrenciler ile nasıl etkileşime girdiği, öğrencileri nasıl sosyalleştirdiğine ilişkin öğretimsel davranımlarını içerir.

Farklı bilim insanları öğrenme stillerini ve buna bağlı olarak öğretim stillerini farklı biçimlerde sınıflamışlardır. Dunn ve Dunn (1993), öğrenme stillerini çevresel ( ses, 1şık, 1s1, oturma düzeni), duygusal ( motivasyon, sorumluluk, iş-görev dağılımı, yapı), sosyal (tek/ikili, akran, takım, yetişkin/çeşitlilik), fizyolojik ( algısal, atş̧ırma, günün saati, hareket) psikolojik ( analitik, bütünsel, yansitıcı, düşünmeci) etmenlere bağlı olarak değiştiğini ileri sürmektedir. Dunn ve Dunn (1993) öğrenme stillerine bağlı olarak öğretmenin öğretim stilini 9 faktörün etkilediğini ileri sürmektedir: eğitim felsefesi, öğrenci tercihleri, öğretimin planlanması, öğrencileri gruplandırma, sınıf düzeni, öğretim ortamı, öğretimin özellikleri, öğretim metotları, değerlendirme teknikleri. Grasha (1997) öğretim stillerini; Uzman (Expert, Otorite (Formal Authority), Kişisel Model (Personal Model), Kolaylaştırıcı (Facilitator), Temsilci (Delegator) şeklinde sınıflamıştır. Fischer \& Fischer (1979) ise öğretim stillerini görev yönelimli, işbirlikli-planlamacı, öğrenci merkezli, konu merkezli, öğrenme merkezli, duygusal olarak coşkulu/durgun şeklinde sinıflandırmıştır.

Öğretim stili sınıflamalarından biri de Center for Occupational Research and Development (CORD) tarafindan yapılmıştır. Bu modelde öğretim, "öğretme amaçları" ve "öğretme yöntemleri” olarak iki şekilde ele alınmaktadır (CORD, 2005). Öğretim amacı iki açıdan yorumlanır. Birinci bakış açısı, genel olarak öğrencilerin edindiği mekanik (ezber) ve mantıksal (kavrama yoluyla) öğrenmeleri ile ilgilidir. İkinci bakış açısı ise öğretmenlerin öğretim etkinliklerinde soyut veya uygulanabilir kavramların, fikirlerin temsil edilmesiyle ilgilidir (Bota \&Tulbure, 2015). CORD öğrenme stilinde öğretim amaçları "öğrenmeye dayall" ve "kavram açıklamaya dayalı" olmak üzere iki boyut vardır. Öğrenmeye dayalı öğretim stilini benimsemiş bir öğretmen için önemli olan sembollerin, ilke ve kavramların öğretiminde kitaptaki bilgilerin olduğu gibi alınmasıdır. Öğretmenler bu stilde daha çok ezbere başvurur. Kavram açıklamaya dayalı öğretim stilinde ise öğretmen bir kavramın tanımının ezberlenmesinden ziyade bu kavramın nasıl, niçin böyle tanımlandığının öğrenciler tarafından anlaşılmasına odaklanır ve öğrenilenler gerçek dünya ile ilişkilendirilir. Öğrenmeye dayalı ve Kavram açıklamaya dayalı bu iki boyut kendi içinde A, B, C, D, olmak üzere dört grupta sınıflanmaktadır. Bu sınıflamaya ait dağılım Şekil 1.'de verilmiştir. 


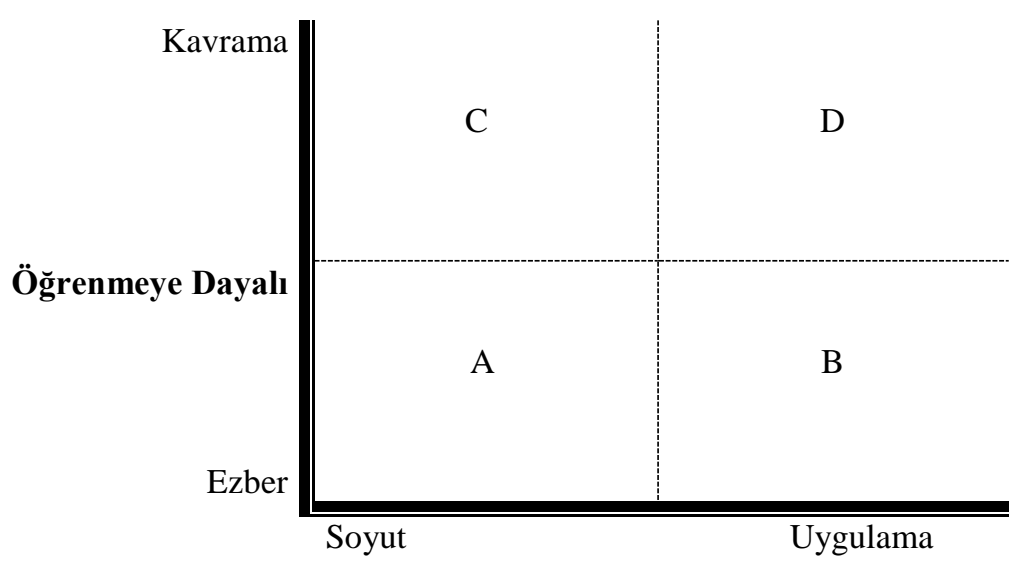

Kavram Açıklamaya Dayalı

Şekil 1. Öğretme Amaçlarına Göre Öğretim Stilleri (CORD,2005).

Stil A, mekanik öğrenmeyi ve soyut öğretimi amaçlar (soyut öğretim). Öğretmen ezberden başlayarak analize doğru öğretmeyi tercih eder. Örneğin öğrenciler çarpım tablosu gibi soyut gerçekleri tekrarlayarak ezberler.

B stili, mekanik öğrenme ve pratik bilgi üzerine kuruludur (uygulamalı öğretim). Öğretmen ezber öğretmenin yanında pratik uygulamalar üzerine de odaklanır. Örneğin öğrenciler dünya hakkındaki pratik gerçekleri uygulamalı olarak öğrenirler.

Stil C kavrama yoluyla öğrenmeyi ve teorik öğretimi amaçlar (soyut öğretim). Bu stil, öğrencilerin faaliyetler yoluyla aktarılan bilgiyi anlamasını desteklediği için öğretime bir değişiklik getirir. Öğrenme süreci, alınan bilgilerin anlaşılması, işlenmesi ve mantıksal olarak öğrenilmesine tabidir. Öğretmen analizden başlayarak ezbere doğru öğretmeyi tercih eder fakat pratik uygulamalar üzerine odaklanmaz. Örneğin öğrenciler soyut süreçleri öğrenirler.

Stil D kavrama yoluyla öğrenmeyi ve pratik bilgiyi (uygulamalı öğretim) amaçlamaktadır. Bu stil, mantıksal öğrenmeyi destekleyen uygulanabilir somut bilgiye odaklanır. Üretkenlik ve verimlilik esastır. Örneğin öğrencilere gerçek dünyaya ilişkin formüle edebilecekleri problemler sunulur (CORD, 2005; Artvinli, 2010; Bota $\&$ Tulbure, 2015)

Örneğin; "Eğitim” kavramının tanımı verecek bir öğretmen öğrenmeye dayalı öğretim stilinde kitaptaki tanımı öğrencilere verir ve bu tanımı olduğu gibi ezberlemelerini ister ya da önce "Eğitim" kavramının tanımında geçen diğer kavramları açıklar ve genel tanımı vererek öğrencilerin bu tanımı anlamalarını ister. Kavram açıklamaya dayalı öğretim stilini benimsemiş bir öğretmen "Eğitim" kavramını öğrencilerin hayatlarında eğitimin ne anlama geldiği üzerinden yola çıkarak, gündelik hayatlarından örneklerle açıklar ve öğrencilerin eğitimin tanımından yola çıkarak kendi hayatlarından örnekler sunmasını ister.

Öğretim stillerinin ikinci boyutu öğretme yöntemleri ile temsil edilmekte olup, iki açıdan gözlemlenmektedir. İlki, kavramların, düşüncelerin ve teorilerin bilişsel işlemesine ve ikincisi, öğrencilerin örgüt yapısını (bireysel veya gruplar) göz önüne alır. CORD öğrenme stilinde ö ğretme yöntemleri "bilişsel sürece dayall” ve "etkileşime dayall” olmak üzere iki boyut vardır. Bilişsel sürece dayalı öğretim stilini benimsemiş öğretmen öğretiminde daha çok bireysel çalışmalara ve öğretmen merkezli öğretim etkinliklerine odaklanır. Etkileşime dayalı öğretim stilini benimseyen öğretmen ise daha çok grup çalışmalarına ve öğrenci-öğretmen, öğrenci-öğrenci etkileşimli öğretim yöntemlerine odaklanır. Bilişsel sürece ve etkileşime dayalı bu iki boyut kendi içinde A, B, C, D, olmak üzere dört grupta sınıflanmaktadır. Bu sınıflamaya ait dağılım Şekil 2.’de verilmiştir. 


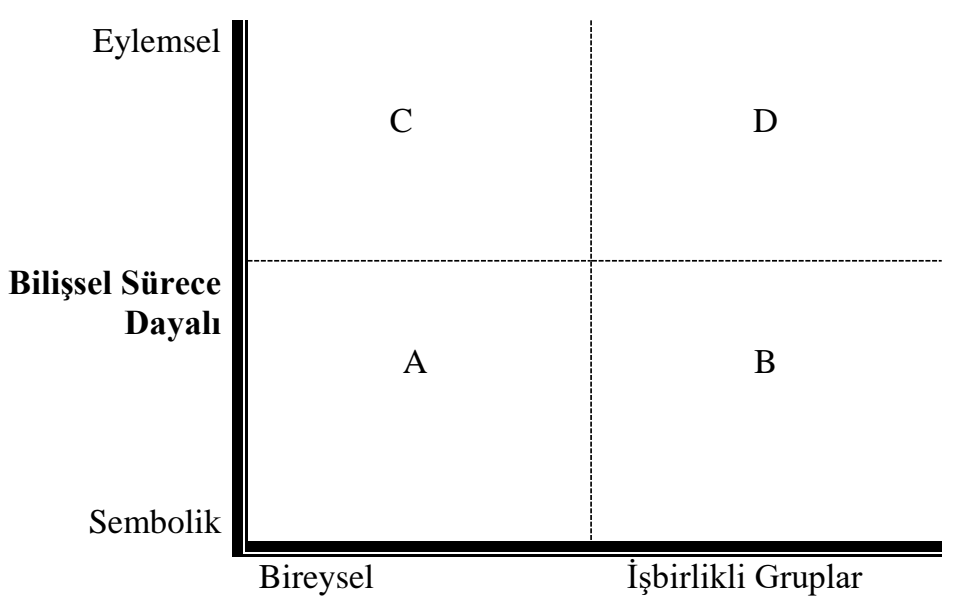

Etkileşime Dayalı

Şekil 2. Öğretme Yöntemlerine Göre Öğretim StilleriCORD,2005). .)

Dört adet öğretim stili de burada bulunmaktadır (CORD, 2005; Artvinli, 2010; Bota \& Tulbure, 2015):

Stil A sembolik bilişsel işleme ve bireysel çalışmayı gerektirir. Başka bir deyişle, öğretmenlerin kullandıkları öğretim yöntemleri en fazla anlatım yöntemidir ve öngörülen öğrenme görevleri bireysel çalışmayı amaçlar. Öğretmen öğrencilerin simgeler ve sözel yol ile bilgi edinmesini sağlar. Örneğin öğretmen konu anlatılmadan önce ön okuma görevleri verir.

Stil B, sembolik bilişsel işleme ve iş birliği grupları. Öğretmen öğrencilerin simgeler ve sözel yol ile bilgi edinmesini sağlar ve grup olarak çalışmalarını tercih eder. Örneğin öğrencilerin gruplara ayrılıp problemleri tartışmaları yapılır.

Stil C, işlenmiş veya yorumlanmış (eylemsel) bilişsel işleme ve bireysel çalışmayı amaçlar. Bu stile göre, öğretmenler, öğrencileri bireysel çalışma yoluyla, yeni bilgiyi keşfetme ve anlamaya teşvik ederler. Örneğin bireysel araştırma etkinlikleri yapılabilir.

Stil D, işlenmiş veya yorumlanmış (eylemsel) bilişsel işleme ve iş birliği grupları. Öğrenciler grup çalışmalarıyla yeni bilgiyi keşfederler ve öğretim sürecine aktif olarak katılırlar. Öğretmen öğrencilerin işbirliğine dayalı olarak tamamlanan pratik etkinliklerle öğrenmelerini sağlar. Örneğin takım çalışmasına dayalı laboratuvar çalışmaları yapilır (CORD, 2005; Artvinli, 2010; Bota \& Tulbure, 2015).

Örneğin; dört işlem gerektiren problemlerin çözümü kavratmak isteyen bir öğretmen bilişsel sürece dayalı öğretim stilini tercih ediyorsa kendisi örnekler üzerinden problem çözümlerini anlatır ve öğrencilerinden örnek problemleri bireysel olarak çözmelerini ister. Etkileşime dayalı öğretim stilini tercih eden öğretmen ise dört işlem problemlerini grup çalışmaları ile öğrencilerine çözdürür, işbirlikçi öğretim teknikleri ile problemlerin çözümüne ilişkin takım çalışmaları yaptırabilir.

Eğitim uygulamaları nasıl etkili hale getirilebilir? Bu uzun yıllardan beri cevaplanmaya çalışılan ve üzerinde araştırmalar yapılan önemli bir sorudur. Öğretmenlerin kullandıkları öğretim stilleri bu kilit sorunun cevabının bir parçasıdır. Dunn ve Dunn'a (1993) göre yapılan araştırmaların hiçbiri öğrencilerin akademik başarıyı nasıl yakaladıkları, bilgiyi nasıl kazandıkları ve depoladıklarını tamamen açıklamaya yetmemektedir. Farklı yaş ve farklı zihinsel kapasitedeki insanlar farklı biçimlerde öğrenirler fakat bazı öğrencilerin akademik başarıyı yakalamaları seçilen öğretim metoduna bağlıdır. Yapılan araştırmalar öğrencilerin öğrenme stillerine uygun öğretim yöntemleri seçilerek öğretim yapıldığında öğrencilerin motivasyonlarının ve akademik başarılarının arttı̆̆ını göstermektedir (Miller 2001; Brown, 2003; Stitt-Gohdes, 2003, Mosston \& Ashworth, 2002; Sümer, 2012). Öğretmenlerin sahip oldukları öğretme stilleri bilgiyi sunuş tarzlarını, öğrencilerle iletişimlerini, sınıf içi ve sınıf dışı etkinlikleri düzenleme biçimlerini etkilemektedir. Bu bağlamda öğretmenlerin öğretme stillerinin belirlenmesi ve çeşitli değişkenler açısından incelenmesinin alana katkı sağlayacağı düşünülmektedir. 
Literatürde öğretmenlerin öğretim stillerinin çeşitli değişkenler açısından incelendiği çalışmalara rastlamak mümkündür. Örneğin Maden (2012) Grasha'nın öğretim stillerine göre Türkçe öğretmenlerinin öğretim stillerini incelemiş, cinsiyet, mesleki kıdem ve mezun olunan bölüm açısından öğretim stillerinin farklılaştığı sonucuna ulaşmıştır. Yine Gencel (2013) Grasha'nın öğretim stillerine göre Türkiye ve ABD’de görev yapan öğretmenlerin öğretim stillerini karşılaştırmış, ABD ve Türkiye'deki öğretmenlerin öğretim stilleri tercihlerinin istatistiksel olarak anlamlı farklılıklar gösterdiğini ortaya koymuştur. ABD'de en fazla tercih edilen öğretim stilinin temsilci/kolaylaştırıc1/uzman, en az tercih edilen öğretim stilinin ise uzman/otorite olduğu belirlenmiştir. Türkiye'de ise kolaylaştırıc1/kişisel model/uzman en fazla tercih edilen öğretim stili iken kişisel model/uzman/otorite en az tercih edilen öğretim stili olmuştur. Üredi (2011) Grasha'nın öğretim stillerine göre ilköğretim öğretmenlerinin öğretim stillerini incelediği çalışma sonucunda öğretmenlerin cinsiyetleri, yaşları, kıdemleri, çalıştıkları okul türü ve en son mezun oldukları okul ile tercih ettikleri öğretim stilleri arasında anlamlı bir ilişki olmadığını, öğretmenlerin görev yaptıkları kademe ve branşları ile tercih ettikleri öğretim stilleri arasında anlamlı bir ilişki olduğunu tespit etmiştir. Sulaiman, Hassan ve Yi (2011) çoklu zeka yaklaşımına göre ilkokul ve ortaokul öğretmenlerinin öğretim stillerinin farklılaştığı sonucuna ulaşmıştır. Cothran, Kulinna, Banville vd. (2005) Mosston'nun öğretim stillerine göre 7 farklı ülkedeki öğretmenlerin öğretim stilleri incelemiş ve ülkelere göre öğretim stillerinin farklılaştığı sonucuna ulaşmıştır. Yukarıda açıklandığı gibi öğretmenlerin öğretim stillerinin çeşitli değişkenler açısından incelendiği çalışmalara rastlamak mümkündür ancak CORD öğretim stilinin ele alındığı ulaşılabilen çalışmalar (Alias ve Zakaria 2008; Artvinli, 2010; Bota \& Tulbure, 2015) kısıtlıdır. $\mathrm{Bu}$ çalışmada hem CORD öğretim stili ele alınmış, hem de farklı branş ve kademelerde çalışan öğretmenlerin öğretim stillerinin çeşitli değişkenler açısından incelenmesi amaçlanmıştır. Bu bakımdan çalışmanın özgün bir çalışma olduğu ve çalışma sonuçlarının alana katkı sağlayacağı düşünülmektedir. Bu düşünceden hareketle bu araştırmada öğretmenlerin öğretim stillerinin çeşitli değişkenler açısından incelenmesi amaçlanmış ve çalışmada aşağıdaki sorulara cevap aranmıştır:

Öğretmenlerin öğretme stilleri;

a) cinsiyetlerine göre

b) branş alanlarına göre

c) görev yaptıkları yerleşim birimine göre

d) derse girdikleri sınıfların ortalama mevcuduna göre

e) eğitim durumuna göre

f) görev yaptıkları okul türüne göre

e) mesleki kıdemlerine göre anlamlı farklılık göstermekte midir?

\section{Yöntem}

Araştırma nicel araştırma modellerinden basit durum nedensel-karşılaştırmalı araştırma olarak tanımlanabilir. Basit durum nedensel-karşılaştırmalı araştırmalarda araştırmacı bir kategorik bağımsız değişken ve bir nicel bağımsız değişken arasındaki ilişkiyi ve bu ilişkinin istatistiksel olarak anlamlı olup olmadığını test eder (Johnson \& Christensen, 2014). Bu araştırmada da öğretmelerin öğretim stilleri öğretmenlerin demografik özellikleri açısından karşılaştırılarak incelenmiştir.

\section{Çalışma Grubu}

Öğretmenlerin seçiminde amaçlı örnekleme yöntemlerinden maksimum çeşitlilik örneklem seçimi kullanılmıştır. Öğretmenler branş, çalıştıkları okulların bulunduğu yerleşim birimi, çalıştıkları okul türleri, cinsiyet, mesleki kıdem açısından çeşitlendirilerek çalışılan durumun geniş bir yelpazede incelenmesi amaçlanmıştır. 2016-2017 eğitim-öğretim yılında Kırklareli’nde görev yapan 248 öğretmenden elde edilmiştir. Çalışma grubuna ait demografik bilgiler Tablo1'de sunulmuştur. 
Tablo1. Çalışma Grubuna Ait Demografik Bilgiler

\begin{tabular}{|c|c|c|c|c|c|c|c|c|}
\hline Cinsiyet & $\mathrm{N}$ & $\%$ & Yerleşim birimi & $\mathrm{N}$ & $\%$ & Sinif mevcudu & $\mathrm{N}$ & $\%$ \\
\hline Kadın & 158 & 63.7 & \multirow{4}{*}{$\begin{array}{l}\text { İl } \\
\text { İlçe } \\
\text { Belde } \\
\text { Köy }\end{array}$} & \multirow{4}{*}{$\begin{array}{l}102 \\
117 \\
20 \\
9\end{array}$} & \multirow{3}{*}{$\begin{array}{l}41.1 \\
47.2 \\
8.1 \\
3.6\end{array}$} & \multirow{4}{*}{$\begin{array}{l}0-20 \\
21-25 \\
26-30 \\
31-35\end{array}$} & 111 & \multirow{4}{*}{$\begin{array}{l}44.8 \\
61.3 \\
83.5 \\
14.9\end{array}$} \\
\hline Erkek & 90 & 36.3 & & & & & \multirow{3}{*}{$\begin{array}{l}41 \\
55 \\
41\end{array}$} & \\
\hline Branş & & & & & & & & \\
\hline $\begin{array}{l}\text { Sözel ('Tarih, } \\
\text { Coğrafya, Sosyal } \\
\text { Bilgiler) }\end{array}$ & 53 & 21.4 & & & 3.6 & & & \\
\hline $\begin{array}{l}\text { Sayısal (Matematik, } \\
\text { Fen, Kimya, Fizik, } \\
\text { Biyoloji) }\end{array}$ & 68 & 27.4 & Kidem yılı & \multicolumn{4}{|c|}{ Okul türü } & \multirow[b]{2}{*}{30.2} \\
\hline $\begin{array}{l}\text { Dil(İngiliz ve } \\
\text { Türkçe) }\end{array}$ & 22 & 8.9 & $0-5$ & 82 & 33.1 & İlkokul & 75 & \\
\hline $\begin{array}{l}\text { Sanat (Resim ve } \\
\text { Müzik) }\end{array}$ & 10 & 4.0 & $6-10$ & 30 & 12.1 & Ortaokul & 82 & 33.1 \\
\hline Beden Eğitimi & 78 & 4.4 & $11-15$ & 35 & 14.1 & Lise & 91 & 36.7 \\
\hline Sinif & 11 & 31.5 & $16-20$ & 28 & 11.3 & & & \\
\hline Okul Öncesi & 6 & 2.4 & 21-üstü & 73 & 29.4 & & & \\
\hline \multicolumn{9}{|l|}{ Eğitim durumu } \\
\hline Lisans tamamlama & 15 & 6.0 & & & & & & \\
\hline Lisans & 215 & 86.7 & & & & & & \\
\hline Yüksek lisans & 18 & 7.3 & & & & & & \\
\hline
\end{tabular}

\section{Veri Toplama Araçları}

Araştırmada veri toplama aracı olarak “CORD Öğretme Stilleri Envanteri” kullanılmıştır. CORD (Center for Occupational Research and Development) tarafindan geliştirilen bu envanter 12 maddeden ve her maddenin altındaki dört durumdan oluşmaktadır. $\mathrm{Bu}$ alt durumlarda öğretmenlerin öğretme yöntemlerine, sınıf içi davranışlarına, düşünme tarzı veya hissettiklerine ilişkin durumlar verilmiştir. CORD tarafından geliştirilmiş olan Öğretme Stilleri Envanteri Artvinli (2010) tarafından Türkçe 'ye uyarlanmıştır. Buna göre ölçme aracında dört farklı öğretme stili ortaya çıkmaktadır. Bu stiller; 1. Öğrenmeye Dayalı (Ezber ve kavrama arasındaki ölçek), 2. Kavram Açıklamaya Dayalı (Soyut/teorik ve uygulama/tatbik arasındaki ölçek), 3. Bilişsel Sürece Dayalı (Simgesel/Sembolik ve gerçek/eylemsel arasındaki ölçek), 4. Etkileşime Dayalı (Bireysel ve işbirlikli gruplar arasındaki ölçek) şeklindedir. Artvinli (2010) tarafından Cronbach Alpha iç tutarlılık katsayısı .88 bulunmuştur. Envanterin dört ayrı alt ölçeğindeki güvenirlik katsayıları ise Öğrenmeye Dayalı için .91, Kavram Açıklamaya Dayalı için .80, Bilişsel Sürece Dayalı boyut için .89, Etkileşime Dayalı alt boyutu için de 92 bulunmuştur. Bu çalışmada da araştırmacılar tarafından 183 kişiye yapılan ön uygulamada Cronbach Alpha iç tutarlılık katsayısı .70 bulunmuştur. Ayrıca, envanterin dört ayrı alt ölçeğindeki güvenirlik katsayıları ise Öğrenmeye Dayalı için .72, Kavram Açıklamaya Dayalı için .81, Bilişsel Sürece Dayalı boyut için .79, Etkileşime Dayalı alt boyutu için de .82 bulunmuştur.

\section{Verilerin Analizi}

Verilerin analizi SPSS 17 kullanılarak yapılmıştır. Genel olarak frekans, aritmetik ortalama ve yüzdeler hesaplanmıştır. Ayrıca verilerin normal dağılım gösterip göstermediğini belirlemek için Kolmogorov-Smirnov testi uygulanmış ve verilerin normal dağılım göstermediği sonucuna ulaşılmıştır. Bu nedenle fark analizinde nonparametrik testlerden olan Mann Whitney-U testi ve Kruskal Wallis-H testi kullanılmıştır. 


\section{Bulgular}

Araştırmaya ilişkin bulgular tablolar şeklinde sunulmuştur.

Tablo 2. Öğretmenlerin Öğretim Stillerinin Cinsiyet Değişkenine Göre Mann Whitney-U Testi Sonuçları

\begin{tabular}{llllll}
\hline Cinsiyet & $\mathbf{N}$ & $\begin{array}{l}\text { Öğrenmeye } \\
\text { dayalı }\end{array}$ & $\begin{array}{l}\text { Kavram açıklamaya } \\
\text { dayalı }\end{array}$ & $\begin{array}{l}\text { Bilişsel sürece } \\
\text { dayalı }\end{array}$ & $\begin{array}{l}\text { Etkileşime } \\
\text { dayalı }\end{array}$ \\
\hline & & $\bar{X}$ & $\bar{X}$ & $\bar{X}$ & $\bar{X}$ \\
$\begin{array}{l}\text { Kadın } \\
\text { Erkek }\end{array}$ & 158 & 121.68 & 123.60 & 127.22 & 127.24 \\
$\begin{array}{l}\text { Toplam } \\
\text { Test } \\
\text { sonucu }\end{array}$ & 248 & 129.44 & 126.08 & 119.73 & 119.68 \\
\hline
\end{tabular}

Tablo 2'de çalışma grubundaki öğretmenlerin öğretim stillerinde cinsiyet değişkenine göre anlamlı bir farklılık olup olmadığını belirlemek amacıyla yapılan Mann Whitney-U testi sonuçları sunulmuştur. Elde edilen bulgulara göre grupların tüm stillere ( öğrenmeye dayalı $\mathrm{Z}=-.82$, $\mathrm{p}>.05$, kavram açıklamaya dayalı $\mathrm{Z}=-.26$, $\mathrm{p}>.0$, bilişsel sürece dayalı $Z=-.79, p>.05$, etkileşime dayalı $Z=-.80, p>.05$ ) ilişkin aritmetik ortalamaları arasındaki fark istatistiksel olarak anlamlı değildir. Elde edilen bulgulara göre öğretmenlerin öğretim stillerinin cinsiyetlerine göre farklılaşmadığı söylenebilir. Öğretmenlerin öğretim stillerinin cinsiyetlerine göre farklılaşmamasına rağmen sıra ortalama puanları incelendiğinde kadın öğretmenlerin daha çok etkileşime dayalı (127.24) ve bilişsel sürece dayalı (127.22), erkek öğretmenlerin ise öğretmeye dayalı (129.44) öğretim stili tercih ettikleri söylenebilir.

Tablo 3. Öğretmenlerinin Öğretim Stillerinin Branş Değişkenine Göre Kruskal Wallis-H Testi Sonuçları

\begin{tabular}{|c|c|c|c|c|c|}
\hline Branş & $\mathbf{N}$ & $\begin{array}{l}\text { Öğrenmeye } \\
\text { dayalı }\end{array}$ & $\begin{array}{l}\text { Kavram } \\
\text { açıklamaya } \\
\text { dayalı }\end{array}$ & $\begin{array}{l}\text { Bilişsel sürece } \\
\text { dayalı }\end{array}$ & Etkileşime dayalı \\
\hline & & $\bar{X}$ & $\bar{X}$ & $\bar{X}$ & $\bar{X}$ \\
\hline Sözel & 53 & 141.49 & 133.31 & 104.11 & 115.84 \\
\hline Sayısal & 68 & 110.65 & 131.48 & 130.63 & 126.56 \\
\hline Dil & 22 & 124.66 & 114.84 & 141.70 & 116.66 \\
\hline Sanat & 10 & 119.25 & 109.95 & 128.70 & 132.60 \\
\hline Sinıf & 78 & 124.75 & 122.78 & 129.73 & 122.47 \\
\hline Beden & 11 & 137.00 & 108.14 & 93.77 & 153.23 \\
\hline \multicolumn{6}{|l|}{ Eğitimi } \\
\hline Okul öncesi & 6 & 113.42 & 79.67 & 153.33 & 166.67 \\
\hline Toplam & 248 & & & & \\
\hline Test sonucu & & $\begin{array}{l}\mathrm{KW} \mathrm{X} \mathrm{X}^{2}=6.07, \\
\mathrm{p}>.01\end{array}$ & $\begin{array}{l}\mathrm{KW} \mathrm{X} X^{2}=55.23, \\
p>.01\end{array}$ & $\begin{array}{l}\mathrm{KW} \mathrm{X} \mathrm{X}^{2}=9.53, \\
\mathrm{p}>.01\end{array}$ & $\mathrm{KW} \mathrm{X} \mathrm{X}^{2}=5.15, \mathrm{p}>.01$ \\
\hline
\end{tabular}

Tablo 3'te çalışma grubunu oluşturan öğretmenlerinin öğretme stillerinin branşlarına göre anlamlı bir farklılık gösterip göstermediğini belirlemek amacıyla yapılan Kruskal Wallis-H testi sonuçları sunulmuştur. Elde edilen bulgulara öğretme stillerine (öğrenmeye dayalı $\mathrm{X}^{2}=6.07, \mathrm{p}>.01$, kavram açılamaya dayalı $\mathrm{X}^{2}=55.23, \mathrm{p}>.0$, bilişsel sürece dayalı $\mathrm{X}^{2}=9.53, \mathrm{p}>.01$, etkileşime dayalı $\mathrm{X}^{2}=5.15, \mathrm{p}>.01$ ) ilişkin aritmetik ortalamalar arasındaki fark istatistiksel olarak anlamlı değildir. Öğretmenlerin öğretim stillerinin branşlarına göre farklılaşmadığı söylenebilir. Branşlara göre öğretim stillerine ilişkin sıra ortalama puanlar incelendiğinde sözel ders öğretmenlerin en çok öğretmeye dayalı (141.49), sayısal ders öğretmenlerinin kavram açıklamaya dayalı (131.48), dil öğretmenlerinin bilişsel sürece dayalı (141.70), sınıf öğretmenlerinin bilişsel sürece dayalı (129.73), sanat öğretmenlerinin etkileşime dayalı (132.60) beden eğitimi öğretmenlerinin etkileşime (153.23) ve okul öncesi öğretmenlerinin etkileşime dayalı (166.67) öğretim stillerini tercih ettikleri görülmektedir. 
Tablo 4. Öğretmenlerinin Öğretim Stillerinin Görev Yaptıkları Yerleşim Birimi Değişkenine Göre Kruskal Wallis-H Testi Sonuçları

\begin{tabular}{|c|c|c|c|c|c|}
\hline $\begin{array}{l}\text { Yerleşim } \\
\text { Birimi } \\
\end{array}$ & $\mathbf{N}$ & Öğrenmeye dayalı & $\begin{array}{l}\text { Kavram } \\
\text { açıklamaya dayalı }\end{array}$ & $\begin{array}{l}\text { Bilişsel sürece } \\
\text { dayalı }\end{array}$ & $\begin{array}{l}\text { Etkileşime } \\
\text { dayalı }\end{array}$ \\
\hline & & $\bar{X}$ & $\bar{X}$ & $\bar{X}$ & $\bar{X}$ \\
\hline İl & 102 & 136.04 & 125.27 & 117.75 & 119.28 \\
\hline İlçe & 117 & 114.31 & 124.72 & 131.38 & 124.59 \\
\hline Belde & 20 & 129.15 & 124.05 & 117.60 & 140.93 \\
\hline Köy & 9 & 115.83 & 113.89 & 126.78 & 145.94 \\
\hline Toplam & 248 & & & & \\
\hline Test sonucu & & $\begin{array}{l}\mathrm{KW} \mathrm{X} X^{2}=5.24 \\
\mathrm{p}>.01\end{array}$ & $\begin{array}{l}\mathrm{KW} X^{2}=-21 \\
p>.01\end{array}$ & $\begin{array}{l}\mathrm{KW} \mathrm{X} \mathrm{X}^{2}=2.18 \\
\mathrm{p}>.01\end{array}$ & $\begin{array}{l}\mathrm{KW} \mathrm{X} \mathrm{X}^{2}=2.41 \\
\mathrm{p}>.01\end{array}$ \\
\hline
\end{tabular}

Kruskal Wallis-H testi sonuçlarına göre öğretmenlerin öğretim stilleri (öğrenmeye dayalı $\mathrm{X}^{2}=5.24, \mathrm{p}>.01$, kavram açıklamaya dayalı, $X^{2}=-21, p>.01$, bilişsel sürece dayalı $X^{2}=2.18, p>.01$, etkileşime dayalı $X^{2}=2.41, p>.01$ ) görev yaptıkları yerleşim birimine göre istatistiksel olarak anlamlı farklılık göstermemektedir. Sıra ortalama puanlar incelendiğinde ise köy ve beldede görev yapan öğretmenlerin daha çok etkileşime dayalı (köy=145.93, belde $=140.93)$ öğretim stili tercih ettikleri, il merkezinde görev yapan öğretmenlerin daha çok öğrenmeye dayalı (136.04) öğretim stilini daha çok tercih ettikleri görülmektedir.

Tablo 5. Öğretmenlerinin Öğretim Stillerinin Görev Yaptıkları Okullardaki Sınıf Mevcuduna Göre Kruskal Wallis-H Testi Sonuçları

\begin{tabular}{llllll}
\hline $\begin{array}{l}\text { Sinıf } \\
\text { mevcudu }\end{array}$ & $\mathbf{N}$ & Öğrenmeye dayalı & $\begin{array}{l}\text { Kavram } \\
\text { açıklamaya dayalı }\end{array}$ & $\begin{array}{l}\text { Bilişsel sürece } \\
\text { dayalı }\end{array}$ & Etkileşime dayalı \\
\hline & & $\bar{X}$ & $\bar{X}$ & $\bar{X}$ & $\bar{X}$ \\
$0-20$ & 111 & 118.41 & 107.11 & 131.86 & 147.22 \\
$21-25$ & 41 & 133.16 & 136.94 & 120.94 & 102.89 \\
$26-30$ & 55 & 120.09 & 130.77 & 125.92 & 117.43 \\
$31+$ & 41 & 138.23 & 150.72 & 106.52 & 94.09 \\
$\begin{array}{l}\text { Toplam } \\
\text { Test sonucu }\end{array}$ & 248 & $\begin{array}{l}\mathrm{KW} \mathrm{X} \mathrm{X}^{2}=3.12 \\
\mathrm{p}>.01\end{array}$ & $\begin{array}{l}\mathrm{KW} \mathrm{X} \mathrm{X}^{2}=-13.70 \\
\mathrm{p}<.01\end{array}$ & $\begin{array}{l}\mathrm{KW} \mathrm{X^{2 }}=3.90 \\
\mathrm{p}>.01\end{array}$ & $\begin{array}{l}\mathrm{KW} \mathrm{X^{2 }}=22.92 \\
\mathrm{p}<.01\end{array}$ \\
\hline
\end{tabular}

Tablo 5'te çalışma grubunu oluşturan öğretmenlerinin öğretme stillerinin öğretmenlerin sınıf mevcudu değişkenine göre anlamlı bir farklılık gösterip göstermediğini belirlemek amacıyla yapılan Kruskal Wallis-H testi sonuçları sunulmuştur. Elde edilen bulgulara göre kavram açılamaya dayalı $\left[\mathrm{KW} \mathrm{X} \mathrm{X}^{2}=-13.70, \mathrm{p}<0.01\right]$ ve etkileşime dayalı $\left[\mathrm{KW} \mathrm{X} \mathrm{X}^{2}=22.92, \mathrm{p}<0.01\right]$ öğretme stillerine ilişkin aritmetik ortalamalar arasındaki fark istatistiksel olarak anlamlı bulunmuştur. Elde edilen farkın hangi gruplar arasında olduğunun saptanması amacıyla yapılan Mann Whitney-U testi sonunda 20 ve daha az sınıf mevcuduna sahip öğretmenlerin 30 ve daha fazla sinıf mevcudu olan öğretmenlere oranla $(U=1462, p<.05)$ kavram açıklamaya dayalı öğretme stilini anlamlı düzeyde daha az kullandıkları sonucuna ulaşılmıştır. Bunun yanı sıra 20 ve daha az sınıf mevcuduna sahip öğretmenlerin 31 ve daha fazla sınıf mevcudu olan öğretmenlere oranla $(\mathrm{U}=1325, \mathrm{p}<.05)$ etkileşime dayalı öğrenme stilini anlamlı düzeyde daha fazla kullandıkları sonucuna ulaşılmıştır. Sıra ortalama puanlar incelendiğinde 21-25, 2630,31 ve üstünde sınıf mevcudu olan öğretmenlerin daha çok kavram açıklamaya dayalı $(21-25=136.94,26-$ $30=130.77,31$ ve üstü=150.72), 20 ve az sinıf mevcudu olan öğretmenlerin ise daha çok etkileşime dayalı (147.22) öğretim stilini tercih ettikleri görülmektedir. 
Tablo 6. Öğretmenlerinin Öğretim Stillerinin Eğitim Durumu Değişkenine Göre Kruskal Wallis-H Testi Sonuçları

\begin{tabular}{|c|c|c|c|c|c|}
\hline $\begin{array}{l}\text { Eğitim } \\
\text { Durumu }\end{array}$ & $\mathbf{N}$ & Öğrenmeye dayalı & $\begin{array}{l}\text { Kavram } \\
\text { açıklamaya dayalı }\end{array}$ & $\begin{array}{l}\text { Bilişsel sürece } \\
\text { dayalı }\end{array}$ & Etkileşime dayalı \\
\hline & & $\bar{X}$ & $\bar{X}$ & $\bar{X}$ & $\bar{X}$ \\
\hline $\begin{array}{l}\text { Lisans } \\
\text { tamamlama }\end{array}$ & 15 & 108.70 & 140.53 & 137.57 & 104.20 \\
\hline Lisans & 215 & 124.75 & 123.51 & 125.20 & 125.67 \\
\hline Y. Lisans & 18 & 134.69 & 122.97 & 105.25 & 127.47 \\
\hline Toplam & 248 & & & & \\
\hline Test sonucu & & $\begin{array}{l}\mathrm{KW} \mathrm{X} X^{2}=1.10, \\
p>.01\end{array}$ & $\begin{array}{l}\mathrm{KW} \mathrm{X}^{2}=.80 \\
\mathrm{p}>.01\end{array}$ & $\begin{array}{l}\mathrm{KW} \mathrm{X} X^{2}=1.82 \\
\mathrm{p}>.01\end{array}$ & $\begin{array}{l}\mathrm{KW} \mathrm{X} X^{2}=1.30 \\
p>.01\end{array}$ \\
\hline
\end{tabular}

Tablo 6'da çalışma grubunu oluşturan öğretmenlerinin öğretme stillerinin öğretmenlerin eğitim durumu değişkenine göre anlamlı bir farklılık gösterip göstermediğini belirlemek amacıyla yapılan Kruskal Wallis-H testi sonuçlarına göre öğretmenlerin öğretim stilleri (öğrenmeye dayalı $\mathrm{X}^{2}=1.10, \mathrm{p}>.01$, kavram açıklamaya dayalı, $\mathrm{X}^{2}=-.80, \mathrm{p}>.01$, bilişsel sürece dayalı $\mathrm{X}^{2}=1.82, \mathrm{p}>.01$, etkileşime dayalı $\left.\mathrm{X}^{2}=1.30, \mathrm{p}>.01\right)$ eğitim durumlarına göre istatistiksel olarak anlamlı farklılık göstermemektedir. Sıra ortalama puanlar incelendiğinde ise eğitim durumu lisans tamamlama olan öğretmenlerin daha çok kavram açıklamaya dayalı (140.53), lisans mezunu olan öğretmenlerin daha çok etkileşime dayalı (125.67), yüksek lisans mezunu olan öğretmenlerin daha çok öğrenmeye dayalı (134.69) öğretim stillerini tercih ettikleri tespit edilmiştir.

Tablo 7. Öğretmenlerinin Öğretim Stillerinin Görev Yaptıkları Okul Türü Değişkenine Göre Kruskal Wallis-H Testi Sonuçları

\begin{tabular}{|c|c|c|c|c|c|}
\hline Okul Türü & $\mathbf{N}$ & $\begin{array}{l}\text { Öğrenmeye } \\
\text { dayalı }\end{array}$ & $\begin{array}{l}\text { Kavram } \\
\text { açıklamaya dayalı }\end{array}$ & $\begin{array}{l}\text { Bilişsel sürece } \\
\text { dayalı }\end{array}$ & Etkileşime dayalı \\
\hline & & $\bar{X}$ & $\bar{X}$ & $\bar{X}$ & $\bar{X}$ \\
\hline İlkokul & 75 & 128.47 & 115.15 & 137.63 & 119.17 \\
\hline Ortaokul & 82 & 120.78 & 121.73 & 130.20 & 125.99 \\
\hline Lise & 91 & 124.58 & 134.71 & 108.54 & 127.55 \\
\hline Toplam & 248 & & & & \\
\hline Test sonucu & & $\mathrm{KW} \mathrm{X} \mathrm{X}^{2}=.45 \mathrm{p}>.01$ & $\mathrm{KW} \mathrm{X}^{2}=3.25 \mathrm{p}>.01$ & $\begin{array}{l}\mathrm{KW} \mathrm{X} X^{2}=1.82 \\
\mathrm{p}>.01\end{array}$ & $\mathrm{KW} \mathrm{X}=1.30, \mathrm{p}>.01$ \\
\hline
\end{tabular}

Tablo 7'den görüldüğü gibi Kruskal Wallis-H testi sonuçlarına göre öğretmenlerin öğretim stilleri görev yaptıkları okul türüne (öğrenmeye dayalı $\mathrm{X}^{2}=.45, \mathrm{p}>.01$, kavram açıklamaya dayalı, $\mathrm{X}^{2}=3.25 \mathrm{p}>.01$, bilişsel sürece dayalı $\mathrm{X}^{2}=1.82, \mathrm{p}>.01$, etkileşime dayalı $\left.\mathrm{X}^{2}=1.30, \mathrm{p}>.01\right)$ göre istatistiksel olarak anlamlı farkl11.k göstermemektedir. Sıra ortalama puanlar incelendiğinde ilkokulda görev yapan öğretmenlerin en çok bilişsel sürece dayalı (137.63), ortaokulda görev yapan öğretmenlerin en çok bilişsel sürece (130.20), liselerde görev yapan öğretmenlerin ise en çok kavram açıllamaya (134.71) öğretim stilini tercih ettikleri görülmektedir.

Tablo 8. Öğretmenlerinin Öğretim Stillerinin Mesleki Kıdem Değişkenine Göre Kruskal Wallis-H Testi Sonuçları

\begin{tabular}{llllll}
\hline Kıdem Yılı & N & Öğrenmeye dayalı & $\begin{array}{l}\text { Kavram } \\
\text { açıklamaya dayalı }\end{array}$ & $\begin{array}{l}\text { Bilişsel sürece } \\
\text { dayalı }\end{array}$ & Etkileşime dayalı \\
\hline & & $\bar{X}$ & $\bar{X}$ & $\bar{X}$ & $\bar{X}$ \\
$0-5$ & & 117.23 & 113.59 & 121.97 & 145.28 \\
$6-10$ & 30 & 115.30 & 115.13 & 148.30 & 126.72 \\
$11-15$ & 35 & 111.69 & 132.04 & 129.40 & 129.56 \\
$16-20$ & 28 & 138.09 & 146.95 & 100.45 & 105.29 \\
$21+$ & 73 & 137.38 & 128.38 & 124.44 & 105.19 \\
Toplam & 248 & & & & \\
Test sonucu & & $\mathrm{KW} \mathrm{X} \mathrm{X}^{2}=5.84 \mathrm{p}>.01$ & $\begin{array}{l}\mathrm{KW} \mathrm{X} \mathrm{X}^{2}=-5.77 \\
\mathrm{p}>.01\end{array}$ & $\begin{array}{l}\mathrm{KW} \mathrm{X}^{2}=6.75 \\
\mathrm{p}>.01\end{array}$ & $\begin{array}{l}\mathrm{KW} \mathrm{X} \mathrm{X}^{2}=11.48 \\
\mathrm{p}<.01\end{array}$ \\
\hline
\end{tabular}


Tablo 8'de çalışma grubunu oluşturan öğretmenlerinin öğretme stillerinin öğretmenlerin kıdem y1lı değişkenine göre anlamlı bir farklılık gösterip göstermediğini belirlemek amacıyla yapılan Kruskal Wallis-H testi sonuçları sunulmuştur. Elde edilen bulgulara göre etkileşime dayalı $\left[\mathrm{KW} \mathrm{X} \mathrm{X}^{2}=11.48, \mathrm{p}<0.01\right]$ öğretme stillerine ilişkin aritmetik ortalamalar arasındaki fark istatistiksel olarak anlamlı bulunmuştur. Elde edilen farkın hangi gruplar arasında olduğunun saptanması amaciyla yapılan Mann Whitney-U testi sonunda 0-5 y1l arasında k1dem yılına sahip öğretmenlerin etkileşime dayalı öğretme stilini 16-20 yıl $(U=2035, p<.01)$ ve $(U=774, p<.01) 21$ y1l ve üzeri kıdeme sahip öğretmenlere oranla anlamlı düzeyde daha fazla kullandıkları sonucuna ulaşılmıştır. Sıra ortalama puanlar incelendiğinde 0-5 yıl arasında mesleki kıdeme sahip öğretmenlerin en çok etkileşime dayalı (145.28), 6-10 arasında mesleki kıdeme sahip öğretmenlerin en çok bilişsel sürece dayalı (148.30), 11-15 yıl arasında mesleki kıdeme sahip öğretmenlerin en çok kavram açıklamaya dayalı (146.95), 21 yıl ve üzeri kıdeme sahip öğretmenlerin ise en çok öğretmeye dayalı öğretim stilini tercih ettikleri görülmektedir.

\section{Tartışma ve Sonuç}

Bir öğretmenin öğretim stili tercihinde birçok etken rol alabilir. Grasha (2002)'ya göre öğretim stilini; öğrencilerin özellikleri ve yetenekleri, öğretmenin kişiler arası verimli ilişkiler geliştirme isteği, öğretmenlerin öğrenme görevini kontrol etme ihtiyac1, öğrencilerin, öğrenme stili ve öğrencilere ait durumsal (o güne ya da o ana ait acil ihtiyaç ve istekler) talepler etkiler. Bu unsurların yanı sıra öğretmenlerin öğretim stilli tercihlerinde deneyimleri, hizmet öncesi aldıkları eğitim, çalıştıkları okul türü gibi demografik özellikler de öğretim stili tercihlerinde belirleyici olabilir düşüncesi ile bu araştırma öğretmenlerin öğretim stilleri farklı değişkenler açısından incelenmiştir.

Araştırmadan elde edilen bulgulara göre öğretmenlerin cinsiyet değişkenine göre öğretim stilleri arasındaki fark istatistiksel olarak anlamlı bulunmamıştır. Ancak Artvinli (2010) coğrafya öğretmenlerinin öğretim stillerinin kavram açıklamaya dayalı ve etkileşime dayalı öğretim stillerinde kadın öğretmenler lehine farklılaştığı, öğrenmeye dayalı stilde ise erkek öğretmenler lehine farklılaştığ 1 sonucuna ulaşmıştır. Buna karşılık bilişsel sürece dayalı öğretme stilinde kadın ve erkek coğrafya öğretmenleri arasında anlamlı bir fark saptamamıştır. Bu çalışmada da sıra ortalama puanlara göre kadın öğretmenler daha çok etkileşime dayalı, erkek öğretmenler ise öğretmeye dayalı öğretim stilini tercih etmektedir. Kadın ve erkek öğretmenlerin öğretim stilleri istatistiksel olarak anlamlı farklılık göstermese de Artvinli 'nin (2010) çalışması ile benzerlik göstermektedir. Literatürde cinsiyet değişkeninin öğretmen/öğretmen adaylarının öğretim stillerinde fark yaratmadığını ortaya koyan çalışmalar (Can; 2011; Üredi, 2011; Zeng, 2016) olduğu gibi, farklılaştığını tespit eden çalışmalar (Lacey, Saleh ve Gorman 1998; Maden, 2012) da bulunmaktadır. Bu durumda cinsiyetin öğretmenlerin öğretim stillerinde belirleyici olup olmadığını söylemek güçtür.

Araştırmadan elde edilen bulgulara göre branş değişkenine göre de öğretmenlerin öğretim stillerinin istatistiksel olarak farklılaşmadığı sonucuna ulaşılmıştır. Sözel ders (tarih, coğrafya, sosyal) öğretmenlerinin sayısal ders (matematik, fizik, kimya) öğretmenlerine oranla öğrenmeye dayalı (daha çok ezber) öğretim stili tercihleri daha yüksektir. Aynı zamanda sanat, beden eğitimi ve okul öncesi ögretmenlerinin etkileşime dayalı öğretim stili tercihleri diğer branş öğretmenlerine göre daha yüksek olmasına rağmen fark istatistiksel olarak anlamlı bulunmamıştır. Alias ve Zakaria (2008) üniversite öğretim üyeleri üzerinde yaptığ 1 araştırmasında teknik eğitim bölümü öğretim üyelerinin mühendislik, teknoloji yönetimi, bilgi teknolojisi öğretim üyelerine göre kavram açıklamaya dayalı öğretim stillini daha az tercih ettikleri sonucuna ulaşmış ve bunu endişe verici bulmuştur. Çünkü öğrencilerin soyut kavramları anlayarak öğrenmesi gerektiğini savunmakta ve geleceğin öğretmenlerin yetiştirilmesinde öğretmeye dayalı öğretim stili yerine kavram açıklamaya dayalı öğretim stilinin daha çok tercih edilmesi gerektiğini dile getirmektedir. Belki de Byrne (2007)'nın ifade ettiği gibi öğretmenler öğrettiği konulardan bağımsız olarak okulda oturmuş olan kültüre göre öğretim stilini belirlemektedir.

Araştırmadan elde edilen bir başka bulguya göre öğretmenlerin öğretim stilleri görev yaptıkları yerleşim birimine göre anlamlı farklılık göstermemektedir. Sıra ortalama puanlara göre ise köy ve beldede görev yapan öğretmenler etkileşime dayalı öğretim stilini daha çok tercih etmekte ve il merkezinde görev yapan öğretmenler öğrenmeye dayalı öğretim stilini daha çok tercih etmektedirler. Farklı ülkelerde görev yapan öğretmenlerin öğretim stilleri görev yaptıkları ülkelere göre farklılaşabilmektedir (Cothran vd., 2005; Gencel, 2013) ancak öğretmenlerin öğretim stilinin bir şehrin yerleşim birimine göre farklılaşmadığı söylenebilir. 
Araştırmadan elde edilen bulgular incelendiğinde öğretmenlerin sınıf mevcudu değişkeninin öğretmenlerin öğretim stili tercihlerinde fark yarattığı sonucu elde edilmiştir. 20 ve daha az sınıf mevcuduna sahip öğretmenlerin 30 ve daha fazla sınıf mevcudu olan öğretmenlere oranla kavram açıklamaya dayalı öğretim stilini anlamlı düzeyde daha az kullandıkları sonucuna ulaşılmıştır. Bunun yanı sıra 20 ve daha az sınıf mevcuduna sahip öğretmenlerin 30 ve daha fazla sınıf mevcudu olan öğretmenlere oranla etkileşime dayalı öğrenme stilini anlamlı düzeyde daha fazla kullandıkları sonucuna ulaşılmıştır. Araştırma sonuçlarına göre sınıf mevcudu daha az olan öğretmenler etkileşime dayalı öğretim stilini daha fazla kavram açıklamaya dayalı öğretim stilini daha az kullanmaktadır. Çalışmadan elde edilen sonuçlar Artvinli (2010)'nin çalışmasında elde edilen sonuçlar ile paralellik göstermektedir. Sınıf sayılarının kalabalık oluşu öğretmemelere grup çalışmaları yapmaya fırsat vermiyor olabilir.

Öğretmenlerin eğitim durumlarına göre öğretim stillerine ilişkin bulgular incelendiğinde ise öğretmenlerin öğretim stillerinde anlamlı bir farklılık olmadığı tespit edilmiştir. Artvinli (2010) eğitim enstitüsü mezunu coğrafya öğretmenlerinin öğrencilerin simgeler ve sözel yol ile bilgi edinmesini, etkileşim olmadan bireysel çalışmasını ve dersi dinlemesini de içeren daha çok öğretmen merkezli ve davranışçı öğretme stillerini uyguladıkları sonucuna ulaşmıştır. Lisansüstü eğitim gören öğretmenlerin ise daha çok etkileşime dayalı öğretim stillerini tercih ettiklerini belirtmekte ve bu sonucun Zhang (2007) tarafından yapılan araştırmada da desteklendiğini dile getirmektedir. Genc ve Ogan-Bekiroglu, (2004) da öğretmenlerin eğitim düzeyinin arttıkça daha çok öğrenci merkezli öğretim stillilerini tercih ettiklerini belirtmektedir. Ancak bu araştırmada öğretmenlerin öğretim stilleri eğitim durumlarına göre anlamlı farklılık göstermemektedir. Bunun yanı sıra ortalama puanlara göre etkileşime dayalı öğretim stilinde lisans ve yüksek lisans mezunu öğretmenlerin ortalaması eğitim durumu lisans tamamlama düzeyinde olan öğretmenlere göre daha yüksektir ancak öğrenmeye dayalı öğretim stilinde en yüksek sıra ortalama puanın yüksek lisans mezunu öğretmenlerde olması çarpıcıdır.

Öğretmenlerin görev yaptıkları okul düzeyi göre (ilkokul, ortaokul, lise) öğretim stillerine ilişkin bulgular incelendiğinde de öğretmenlerin öğretim stillerinde anlamlı bir farklılık olmadığı tespit edilmiştir. Sıra ortalama puanlara göre ilkokul ve ortaokulda görev yapan öğretmenlerin daha çok bilişsel sürece dayalı, liselerde görev yapan ögretmenlerin ise daha çok kavram açıklamaya öğretim stilini tercih ettikleri tespit edilmiştir. Artvinli (2010) görev yapılan okul türüne göre kavram açıklamaya dayalı öğretim stilinde coğrafya öğretmenlerin öğretim stillerinin farklılaştığı sonucuna ulaşmıştır. Buna göre kavram açıklamaya dayalı öğretme stilinde Anadolu, Fen, Sosyal Bilimler Liselerinde görev yapan öğretmenler ile meslek liselerinde görev yapan öğretmenler arasında Anadolu, Fen, Sosyal Bilimler Liselerinde görev yapan öğretmenler lehine fark çıkmıştır. Artvinli (2010)'ye göre bu fark birinci gruptaki okul türlerinde üniversite sınavı kaygısı ile daha çok ezbere dayalı coğrafya eğitimi yapıldığ 1 şeklinde yorumlanmıştır. Bu araştırmada da lise öğretmenlerinin ilkokul ve ortaokul öğretmenlerine göre kavram açıklamaya dayalı öğretim stili ortalamalarının yüksek oluşu üniversite sınavına hazırlık kaygısından kaynaklanıyor olabilir.

Araştırmadan elde edilen bir diğer bulgu ise; öğretmenlerin kıdem değişkeninin öğretmenlerin öğretim stili tercihlerinde fark yarattığıdır. 0-5 yıl arasında kıdem yılına sahip öğretmenlerin etkileşime dayalı öğretme stilini 16-20 yıl ve 21 yıl ve üzeri kıdeme sahip öğretmenlere oranla anlamlı düzeyde daha fazla kullandıkları sonucuna ulaşılmıştır. Benzer sonuçlar Artvinli (2010) ve Alias ve Zakaria (2008) çalışmalarında da yer almaktadır. Ülkemizde uygulanan öğretim programlarında işbirliğine dayalı öğretim yöntemlerinin kullanılması ve öğrencinin bilgiyi pasif olarak alması değil, etkinlikler yoluyla bilgiyi yapılandırması yani derste öğrencinin aktif, öğretmenin ise rehber olması beklenmekte, başka bir değişle öğretimin yapılandırmacı yaklaşım esasına göre yürütülmesi gerekmektedir (MEB, 2005). Eğitim fakültelerinin programları bilgi, beceri, değer kazanımlarının yanında sistemli ve planlı bir şekilde adayların öğretmenlik deneyimi kazanmalarına imkân sağlar. Bu deneyim fakülte-okul işbirliği içerisinde yürütülür. Türkiye'de fakülte-okul işbirliği içerisinde yürütülen bu deneyimle öğretim biçimi yapılandırmacı yaklaşımın bir örneği olarak değerlendirilebilir (Kaya, 2016). Bu bağlamda özellikle 1-5 yıl arasındaki kıdeme sahip öğretmenlerin hizmet öncesinde eğitimde yapılandırmacı anlayışa göre yetiştikleri düşünülebilir. Yüksek kıdeme sahip öğretmenlerin ise daha çok geleneksel yöntemlere bağlı kalmış olabilir. Öğrenci merkezli öğretim stiline sahip olan öğretmenler yapılandırmacı ortamları hazırlamada daha başarılıdır (Üredi ve Üredi 2009). Öğrenmeden öğretilemeyeceğine göre öğretmen adaylarının, öğretmen yetiştirme programlarında bulundukları sıralarda öğretme öğrenme kuram, strateji ve stilleri konularında yetiştirilmelerinin büyük önemi vardır. Böylece yöntem bileşenleri açısından daha geniş öngörülü öğreticiler yetiştirmek olası olacaktır (Babadoğan, 2000). 
Araştırma sonuçlarına göre sınıf mevcudu düşük olan öğretmenler etkileşime dayalı öğretim stilini tercih etmektedir. Bu bağlamda öğretmenlerin sınıf içi aktivitelere ve grup çalışmalarına fırsat vermesi için sınıf mevcutlarının düşürülmesine yönelik çalışmalar yapılması önerilebilir.

Araştırmadan elde edilen bir başka sonuca göre mesleki kıdemi az olan öğretmenlerin etkileşime dayalı öğretim stilini daha çok tercih ettikleri düşünüldüğünde özellikle mesleki kidemi fazla olan öğretmenlere geleneksel yöntemlerden sıyrılmaları için hizmet içi eğitim seminerleri düzenlenebilir.

Öğretmenlerin öğretim stillerinde cinsiyet, branş, eğitim durumu, okul türü vb. değişkenlerin etkisinin araştırılacağı daha geniş çaplı araştırmalar yapılabilir. Öğretmelerin öğretim stilleri tercihlerinde hangi değişkenlerin belirleyici olduğuna yönelik öğretmen görüşlerinin alınacağı nitel araştırmalar yapılabilir.

\section{Bilgilendirme}

Bu çalışma IX. Uluslararası Eğitim Araştırmaları Kongresi'nde özet metin olarak sunulmuştur. 


\section{References}

Alias, M., \& Zakaria, N. (2008). Methods of teaching and goals of teaching: Teaching styles of teachers in higher institutions. In: Seminar Kebangsaan Jawatakuasa Penyelarasan Pendidikan Guru (JPPG), Langkawi, Malaysia.

Artvinli, E. (2010). Coğrafya öğretmenlerinin öğretme stilleri. Online Journal of Social Sciences, 9 (33), 387-408.

Babadoğan, C. (2000). Öğretim stili odaklı ders tasarımı geliştirme. Milli Ĕ̆itim Dergisi, 147, 61-63.

Bota, O. A., \& Tulbure, C. (2015). Aspects Regarding the Relationship between Teaching Styles and School Results. Procedia-Social and Behavioral Sciences, 203, 285-290.

Brown, B. L. (2003). Teaching Style vs. Learning Style Myths and Realities. ERIC ED: 482 329. Retrieved 20 October 2017, from http://files.eric.ed.gov/fulltext/ED482329.pdf

Byrne, E P. (2007). Teaching \& learning styles in engineering at UCC. International Symposium for Engineering Education, 2007, Dublin City University, Ireland. Retrieved 20 October 2017, from http://www.ndlr.ie/mecheng/symp/papers/LSED/Byrne_TLStyles_ISEE07.pdf

Can, Ş. (2011). Sınıf öğretmeni adaylarının öğrenme stilleri ile bazı değişkenler arasındaki ilişkinin araştırılması. Hacettepe Üniversitesi Ĕgitim Fakültesi Dergisi, 41(41),70-82.

Cooper, J. (1999). Classroom teaching skills. Boston: Houghton Mifflin

CORD (2005). Retrieved 14 May 2017, from http: //.texascollaborative.org/tools/TSI.pdf.

Cothran, D. J., Kulinna, P. H., Banville, D., Choi, E., Amade-Escot, C., MacPhail, A., Macdonald, D. , Richard, J.F. , Sarmento, P.\& Kirk, D. (2005). A cross-cultural investigation of the use of teaching styles. Research quarterly for exercise and sport, 76(2), 193-201.

Dunn, R. \& Dunn, K. (1993). Learning Styles/Teaching Styles: Should They...Can They... Be Matched. Educational leadership, 36 (4). 238-244

Çetinkaya, S. \& Eskici, M. (2018). Öğretmenlerin öğretmeye yönelik metaforik algıları. Akdeniz Ĕ̆itim Araştırmaları Dergisi, 12(24), 253-271.

Gencel, I. E. (2013). Öğretmenlerin öğretim stilleri tercihleri: Türkiye-ABD karşılaştırılması. Turkish StudiesInternational Periodical For The Languages, Literature and History of Turkish or Turkic, 8(8), 635-648.

Fischer, B.B. \& Fischer, L. (1979). Styles in teaching and learning. Educational leadership 36(4), 245-254.

Genç, E. \& Ogan-Bekiroğlu, F. (2004). "Patterns in teaching styles of science teachers in Florida and factors influencing their preferences", Florida Educational Research Association (FERA) Kongresi Bildiriler Kitab1, Gainesville, FL, ABD. Retrieved 9 September 2017, from http://www.eric.ed.gov/ERICDocs/ data/ericdocs2sq1/content_storage_01/0000019b/ 80/1b/c4/3a.pdf,

Grasha, A. F. (1997). Teaching with style. Pittsburgh, PA: Alliance.

Grasha, A. F. (2002). The Dynamics of One-On-One Teaching. College Teaching, 50 (4), 139-146

Grasha, A. F. (2003). Teaching with Style: The Integration of Teaching and Learning Styles in the Classroom. Center for Teaching Excellence, 17 (5), 1995-96.

Irby, D.M. (1995). Teaching and learning in ambulatory care settings: Athematic review of the literature. Acad Med. 70, 898-931.

Johnson, B., \& Christensen, L. (2014). Eğitim araştırmaları: Nicel, nitel ve karma yaklaşımlar. (Trans. Ed. S. B. DEMIR) Ankara: Eğiten Kitap.

Kaya, M. (2016). Öğretmen yetiştirme standartları konusunda bir sistematik literatür inceleme. Unpublished Doctoral dissertation. Osmangazi Universty, Eskişehir. 
Kolb, A. Y. \& Kolb, D. A. (2005). The Kolb learning style inventory-version 3. Technical specifications. Boston, MA: Hay Resource Direct, 200 (72), 1-72.

Kolb, D. A. (1984). Experiential learning: Experience as the source of learning and development. New Jersey: Prentice Hall

Lacey, C. H., Saleh, A., \& Gorman, R. (1998). Teaching Nine to Five: A Study of the Teaching Styles of Male and Female Professors. Women in Educational Leadership Annual Conference, Lincoln. Retrieved 5 October 2017 from: https://files.eric.ed.gov/fulltext/ED442334.pdf

Maden, S. (2012). Türkçe öğretmenlerinin öğretme stilleri. Uluslararası Türkçe Edebiyat Kültür Eğitim Dergisi.1(1),178-200.

MEB (2005). Öğretim Programları. Talim Terbiye Kurulu. . Retrieved 8 October 2017 from: https://ttkb.meb.gov.tr/

Miller, P. (2001). Learning Styles: The Multimedia of the Mind. Research Report. ERIC ED: 451140 Retrieved 9 September 2017, from http://files.eric.ed.gov/fulltext/ED451140.pdf

Mosston, M.\& Ashworth, S. (2002). Teaching Physical Education (5 $5^{\text {th }}$ Ed.). San Francisco: Benjamin Cummings.

Stitt-Gohdes, W. L. (2003). Student Teachers and Their Students: Do Their Instructional and Learning Preferences Match? In Business Education Forum, 57 (4), 22-27

Sulaiman, T., Hassan, A., \& Yi, H. Y. (2011). An analysis of teaching styles in primary and secondary school teachers based on the theory of multiple intelligences. Journal of Social Sciences, 7(3), 428.

Aktan, S. (2012). Öğrencilerin akademik başarısı, öz düzenleme becerisi, motivasyonu ve öğretmenlerinin öğretim stilleri arasındaki ilişki. Unpublished Doctoral dissertation. Balıkesir Universty, Balıkesir.

Üredi, L. (2011). İlköğretim öğretmenlerinin öğretim stili tercihlerine ile demografik özellikleri arasındaki ilişki. E-Journal of New World Sciences Academy, 6(1), 1129-1141.

Üredi, I.T. \& Üredi, L. (2009). Yapılandırmacı öğrenme ortamı üzerinde etkili olabilecek bir değişken: öğretim stili tercihi. E-Journal of New World Sciences Academy, 4(4), 1171-1185

YÖK.(2011). Türkiye yükseköğretim yeterlilikler çerçevesi (tyyç) temel alan yeterlilikleri: Öğretmen yetiştirme ve eğitim bilimleri. Retrieved 8 October 2017, from http://tyyc.yok.gov.tr.

Zeng, H. Z. (2016). Differences Between Student Teachers' Implementation and Perceptions of Teaching Styles. Physical Educator, 73(2), 285.

Zhang, Li- F. (2007). Do personality traits make a difference in teaching styles among Chinese high school teachers? Personality and Individual Differences, 43, 669-679. 